\title{
Lagrangian analysis of low altitude anthropogenic plume processing across the North Atlantic
}

\author{
E. Real ${ }^{1, *}$, K. S. Law ${ }^{1}$, H. Schlager ${ }^{2}$, A. Roiger ${ }^{2}$, H. Huntrieser ${ }^{2}$, J. Methven ${ }^{3}$, M. Cain ${ }^{3}$, J. Holloway ${ }^{4}$, J. A. Neuman ${ }^{4}$, \\ T. Ryerson ${ }^{5}$, F. Flocke ${ }^{6}$, J. de Gouw ${ }^{4}$, E. Atlas ${ }^{7}$, S. Donnelly ${ }^{8}$, and D. Parrish ${ }^{5}$ \\ ${ }^{1}$ Service d'Aéronomie/UPMC, CNRS-IPSL, 4 Place Jussieu, 75005 Paris, France \\ ${ }^{2}$ Deutsches Zentrum für Luft- und Raumfahrt (DLR), Oberpfaffenhofen, Institut für Physik der Atmosphäre, \\ 82230 Wessling, Germany \\ ${ }^{3}$ Department of Meteorology, University of Reading, P.O. Box 243, Earley Gate, Reading, RG6 6BB, UK \\ ${ }^{4}$ NOAA ESRL/CIRES, University of Colorado at Boulder, Boulder CO 80309, USA \\ ${ }^{5}$ NOAA ESRL, 325 Brodway, Boulder, CO 80305 USA \\ ${ }^{6}$ Atmospheric Chemistry Division, NCAR, 1850 Table Mesa Drive Boulder, CO 80305 USA \\ ${ }^{7}$ RSMAS/MAC University of Miami, Miami, FL 33149 USA \\ ${ }^{8}$ Department of Chemistry, Fort Hays State University, Hays KS 67601 USA \\ *now at: CEREA, Paris Est, 20 rue Alfred Nobel 77455, Champs sur Marne, France
}

Received: 12 March 2008 - Published in Atmos. Chem. Phys. Discuss.: 17 April 2008

Revised: 24 November 2008 - Accepted: 24 November 2008 - Published: 23 December 2008

\begin{abstract}
The photochemical evolution of an anthropogenic plume from the New-York/Boston region during its transport at low altitudes over the North Atlantic to the European west coast has been studied using a Lagrangian framework. This plume, originally strongly polluted, was sampled by research aircraft just off the North American east coast on 3 successive days, and then 3 days downwind off the west coast of Ireland where another aircraft re-sampled a weakly polluted plume. Changes in trace gas concentrations during transport are reproduced using a photochemical trajectory model including deposition and mixing effects. Chemical and wet deposition processing dominated the evolution of all pollutants in the plume. The mean net photochemical $\mathrm{O}_{3}$ production is estimated to be $-5 \mathrm{ppbv} / \mathrm{day}$ leading to low $\mathrm{O}_{3}$ by the time the plume reached Europe. Model runs with no wet deposition of $\mathrm{HNO}_{3}$ predicted much lower average net destruction of $-1 \mathrm{ppbv} / \mathrm{day} \mathrm{O}_{3}$, arising from increased levels of $\mathrm{NO}_{\mathrm{x}}$ via photolysis of $\mathrm{HNO}_{3}$. This indicates that wet deposition of $\mathrm{HNO}_{3}$ is indirectly responsible for $80 \%$ of the net destruction of ozone during plume transport. If the plume had not encountered precipitation, it would have reached Europe with
\end{abstract}

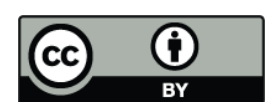

Correspondence to: E. Real (elsa.real@aero.jussieu.fr)
$\mathrm{O}_{3}$ concentrations of up to 80 to $90 \mathrm{ppbv}$ and $\mathrm{CO}$ between 120 and 140 ppbv. Photochemical destruction also played a more important role than mixing in the evolution of plume $\mathrm{CO}$ due to high levels of $\mathrm{O}_{3}$ and water vapour showing that $\mathrm{CO}$ cannot always be used as a tracer for polluted air masses, especially in plumes transported at low altitudes. The results also show that, in this case, an increase in $\mathrm{O}_{3} / \mathrm{CO}$ slopes can be attributed to photochemical destruction of $\mathrm{CO}$ and not to photochemical $\mathrm{O}_{3}$ production as is often assumed.

\section{Introduction}

It is recognised that emissions from large urban/industrial regions can have large-scale impacts on concentrations of $\mathrm{O}_{3}$, particles, and other trace constituents downwind from continents. These impacts are important because they may affect the ability of downwind countries to meet air quality standards, and because of climate impacts of $\mathrm{O}_{3}$ and particles through radiative forcing. Anthropogenic pollution occurs primarily in the boundary layer (BL) over continents. This pollution may then be transported at low levels directly impacting the BL of a downwind continent or may be exported from the BL into the mid and upper troposphere by frontal systems or convection and transported at higher altitudes $(\mathrm{Li}$

Published by Copernicus Publications on behalf of the European Geosciences Union. 
et al., 2005). Because of lower water vapour and temperature, loss processes are less active and pollutant lifetimes longer in the upper troposphere. However, high altitude plumes are less likely to directly impact the BL composition of a downwind continent. Several modelling studies have already shown that long-range transport of pollutants from North America to Europe is one of the most important due to large emissions and the relative proximity of the two continents (Wild and Akimoto, 2001; Stohl, 2001; Stohl et al., 2002). There is clear experimental and modelling evidence for such export from North America at both low and high altitudes. Polluted plumes have been sampled at remote surface sites such as Sable Island or Chebogue Point (Parrish et al., 1998; Millet et al., 2006), off the New England coast, and also downwind in the Azores (Parrish et al., 1998; Owen et al., 2006) in the mid-Atlantic Ocean. Analysis of these polluted plumes showed that they were usually transported at low altitudes, below $3 \mathrm{~km}$. Modelling studies suggest that one third of $\mathrm{CO}$ exported from North America occurs in the lowest $3 \mathrm{~km}$ (Li et al., 2005) and Owen et al. (2006) suggested that low level transport of North American pollution above the marine BL may provide an effective mechanism for long-range transport of anthropogenic pollution over the North Atlantic with a resulting impact on lower tropospheric $\mathrm{O}_{3}$ in downwind regions.

Whilst there have been several measurements of polluted plumes with North American origins in the free troposphere over Europe (e.g. Huntrieser et al., 2005), there have been fewer detailed cases at low levels and the impact of such long-range transport on $\mathrm{O}_{3}$ levels in the European $\mathrm{BL}$ is not well documented (Derwent et al., 1998). Ground-based sites on the west coast of Europe do occasionally observe such cases. For example, Li et al. (2002) reported several measurements of moderately polluted plumes at Mace Head (west coast of Ireland) with weak enhancements in $\mathrm{CO}$ and $\mathrm{O}_{3}$. Despite the relative lack of experimental evidence, global model simulations suggest that the impact of anthropogenic North American pollution on European $\mathrm{BL} \mathrm{O}_{3}$ is important. Li et al. (2002) and Auvray and Bey (2005) estimated an increase of 2 to 4 parts per billion by volume (ppbv) in European $\mathrm{O}_{3}$ concentrations during summer, which could be responsible for $20 \%$ of the violation of the European Union threshold for $\mathrm{O}_{3}$. These studies suggest that half of the import of North American $\mathrm{O}_{3}$ in the BL is due to transport at low altitudes with the remainder due to subsidence of high altitude plumes. Derwent et al. (2004) suggested a higher value of $8 \mathrm{ppbv}$ increase in the European BL using an $\mathrm{O}_{3}$ tracer technique in a semi-Lagrangian global model. During high pollution events, under conditions typified by a strong Icelandic Low located between Iceland and the British Isles, Auvray and Bey (2005) simulated an increase in European $\mathrm{O}_{3}$ due to North American pollution of more than than 10 ppbv. Several explanations have been proposed for the difference between the non-negligible impact of North American pollution on European $\mathrm{O}_{3}$ simulated by models and the lack of experimental evidence. Stohl et al. (2002) suggested that North American pollution reaches the European BL primarily south of the Pyrenees where measurement sites are sparse, and also that North American plumes are generally older then 10 days when reaching Europe, and therefore, hard to accurately trace back to sources.

In this study, we address these issues through the analysis of data collected in a pollution plume transported at low altitudes over the North Atlantic as part of the International Consortium for Atmospheric Research on Transport and Transformation (ICARTT) (Fehsenfeld et al., 2006) also encompassing the European Intercontinental Transport of Ozone and Precursors (ITOP) experiment, which took place in summer 2004. As part of this campaign, the International Transport and Chemical Transformation (ITCT) Lagrangian 2K4 experiment (an International Global Atmospheric Chemistry (IGAC) task) executed a Lagrangian study of polluted air masses transported across the North Atlantic. Four research aircraft based in North America, the Azores and western Europe sampled the same air masses several times during long-range transport. Lagrangian experiments have been conducted previously, but this was the first time that a Lagrangian experiment was conducted in the free troposphere on intercontinental scales. The main advantage of this kind of study is that changes in plume concentrations over several days can be estimated by comparing two Lagrangian samplings, and the processes leading to these changes can be evaluated with reduced uncertainty. After the campaign a detailed analysis using trajectories, a Lagrangian dispersion model, and in-situ measurements was performed by Methven et al. (2006), and showed that there were five cases where the same air mass had been sampled several times across the Atlantic.

The overall goal of this paper is to improve our understanding about low altitude long-range transport of anthropogenic plumes over the North Atlantic and their impact on $\mathrm{O}_{3}$ and precursors levels over Europe. In particular, we analyse the evolution of a North American plume observed during the Lagrangian 2K4 experiment which was originally very polluted, and then transported at low levels over the North Atlantic toward Europe. The aim is also to determine the relative importance of processes influencing its chemical composition, and to explain why polluted North American plumes are not easily detected at surface measurement sites in Europe.

The Lagrangian plume in question originated from the New York-Boston conurbation and was sampled 3 times just off the New England coast on 3 successive days by the National Oceanic and Atmospheric Administration (NOAA) P3, and then, 2 days later off the west coast of Ireland, and 3 days later over the English Channel by the German Deutsches Zentrum fur Luft- und Raumfahrt (DLR) Falcon. First, the Lagrangian matches identified by Methven et al. (2006) are discussed in Sect. 2 together with the observed chemical evolution of pollutants during the plume transport. Cases where 
the Lagrangian matching is less good due to the influence of other processes such as mixing with local emissions are also identified. Next, to evaluate the relative contributions of chemical, physical and dynamical processes to changes in $\mathrm{O}_{3}$ concentrations in the plume during transport, a photochemical trajectory model was used (Sect. 3). In Sect. 4, results are presented from model runs initialised with upwind data over New England, and compared to downwind data over Europe. The model was run along a trajectory representative of the mean plume transport pathway and giving the best match between plume samplings. The model was first run with chemistry only (Sect. 4.1), and then including wet and dry deposition (Sect. 4.2). The sensitivity of the results to heterogeneous loss on aerosols was also analysed. The impact of mixing with air masses in close proximity to the plume is examined in Sect. 4.3. The ability of the model to simulate the contribution of photochemical processes to $\mathrm{O}_{3}$ changes in the plume was further tested by examining the evolution of trace gas correlations using multiple model runs initialised across the first plume sampling (Sect. 4.4). Conclusions are presented in Sect. 5.

\section{Lagrangian case: measurements and analysis}

\subsection{Identification of Lagrangian matches}

Methven et al. (2006) used a novel technique to identify Lagrangian matches between flight segments from different aircraft during the entire IGAC Lagrangian $2 \mathrm{~K} 4$ experiment in July 2004. This technique combined trajectories, calculated using global meteorological analysis (European Centre for Medium Range Weather Forecast 40 year Reanalysis - ERA40), and hydrocarbon fingerprint analysis. A match was defined as an occasion when a pair of whole air samples (analysed for their hydrocarbon content) collected during different flights exhibited highly correlated hydrocarbon fingerprints (when such measurements were available), and the sample time windows were also connected by both backward and forward trajectories. Results from the Lagrangian particle dispersion model, FLEXPART, run with CO tracers (Stohl et al., 2004) were also used to confirm matches. Five clear Lagrangian cases covering a variety of situations were identified. Further details can be found in Methven et al. (2006).

In this paper, we build on the work of Real et al. (2007) which focused on the Lagrangian analysis of the long-range transport of a forest fire plume during ICARTT, one of the cases discussed by Methven et al. (2006). Here, we examine another case from Methven et al. (2006) where an anthropogenic pollutant plume was transported across the North Atlantic at low altitudes. The plume from the New YorkBoston region was first sampled by the NOAA P3 over the Gulf of Maine and Nova Scotia on 3 successive days (20, 21, 22 July), and then by the DLR Falcon flying just off the coast of Ireland on 25 July and over the English Chan-
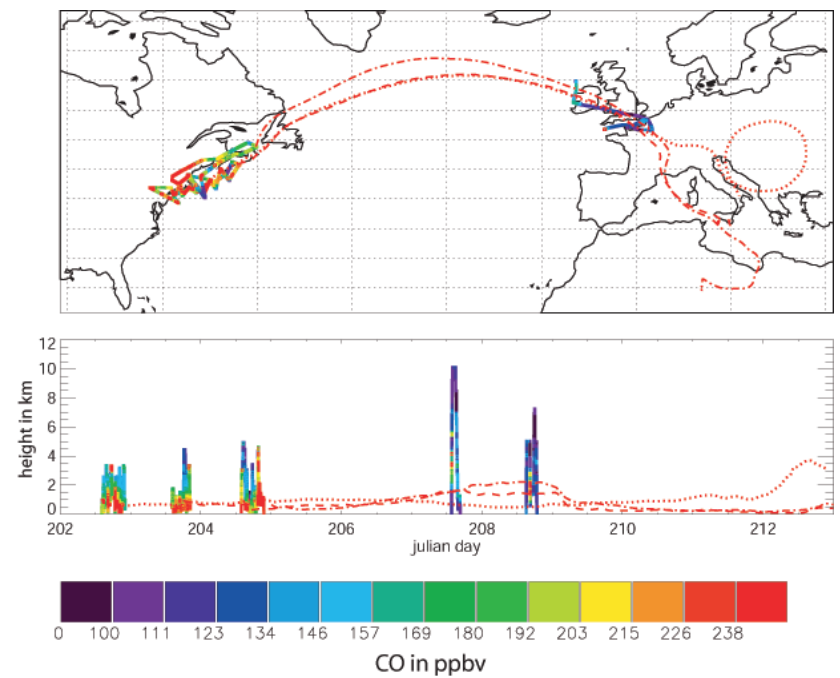

Fig. 1. Flight tracks of P3 flights on 20, 21, and 22 July 2004 and Falcon flights on 25 and 26 July 2004, coloured with measured CO. Three forward trajectories initialised in the 3 Lagrangian samplings of the P3 are also shown for 20 (dotted), 21 (dashed) and 22 (dashed-dotted) July 2004, respectively.

nel on 26 July 2004. The flight tracks of these 5 flights are shown in Fig. 1. The segments of the 3 flights identified as Lagrangian matches were labelled as Lagrangian case 3 by Methven et al. (2006). The same Lagrangian time windows are used in this study. The ability of the Methven et al. (2006) analysis to identify Lagrangian matches has been shown to work well in the free troposphere where transport is mainly driven by advection (Real et al., 2007). However, at low altitudes, certain meteorological features are not so well resolved by analysed winds, and can induce errors in the Lagrangian analysis. For example, Riddle et al. (2006) analysed the ability of trajectory models to represent air mass transport during the ICARTT campaign by using Lagrangian balloons released over north-east North America. Balloons were launched close to the Lagrangian match of the NOAA-P3 aircraft on 20 July. On 21 July, the balloon location and aircraft Lagrangian match were very well co-located (less than $2 \mathrm{~km}$ apart) suggesting that the matching between these 2 samples is good. This is not the case for 22 July where the balloon was located far from the Lagrangian match. Indeed, important differences were found between balloon and model trajectories between 21 and 22 July over the Newfoundland coast, possibly due to poor simulation of strong coastal winds in the ECMWF analyses. Also, hydrocarbon matches on 22 July were the least consistent (with increases in hydrocarbon concentrations compared to the 2 previous days - see next section). Therefore, it appears that Lagrangian match between 20, 21 July and 22 July is less good. The accuracy of the Lagrangian samplings is examined further in the next section where the observations in the plume segments are discussed. 

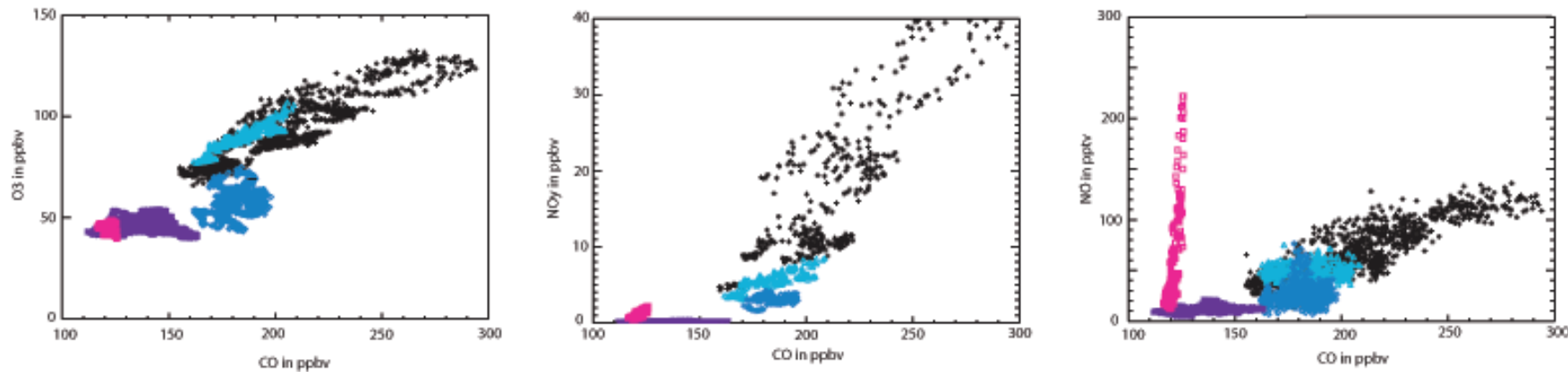

Fig. 2. Measured $\mathrm{O}_{3}$ and reactive nitrogen concentrations $\left(\mathrm{NO}, \mathrm{NO}_{\mathrm{y}}\right.$ ) versus measured $\mathrm{CO}$ in the 5 Lagrangian match samplings. Black crosses represent measurements taken on 20 July and light blue triangles, dark blue diamonds, violet stars and pink squares the measurements taken on 21, 22, 25 and 26 July 2004, respectively.

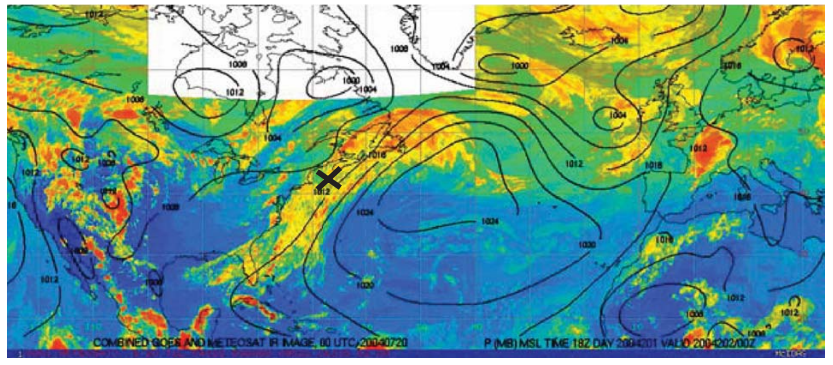

20 July

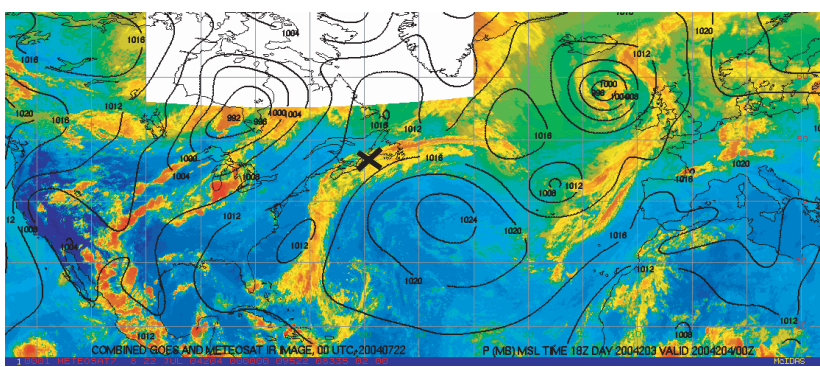

22 July

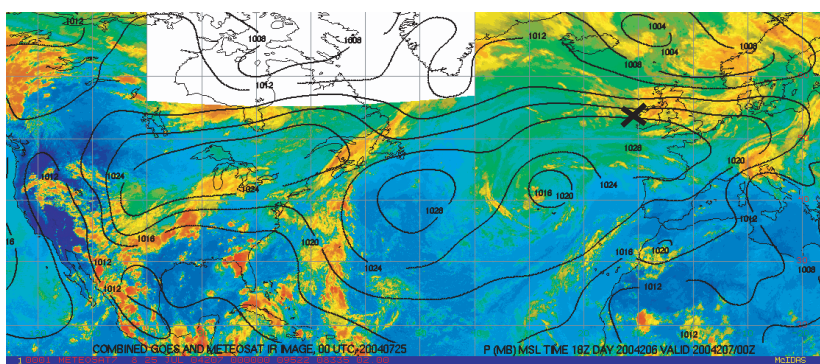

25 July

Fig. 3. Infrared images combined from GOES and METEOSAT for 20, 22 and 25 July 2004 taken from the NOAA products in support of ICARTT (courtesy O. Cooper, NOAA ESRL). Black lines are surface pressure $(\mathrm{hPa})$ and black crosses represent the location of the Lagrangian matches on each day.
The meteorological situation during plume transport has been examined using the Geodetic Earth Orbiting Satellite GOES-1 and METEOSAT satellite images superimposed with surface pressure values (see Fig. 3). On 19 July, a cold front passed over the north-east coast of the United States (US). Behind this front, strong outflow took place below $3 \mathrm{~km}$ transporting air from the New York-Boston region on 20 July towards Newfoundland on 22 July. From the 22 to 25 July, strong winds established over the Atlantic Ocean between the Azores/Bermuda High and the Icelandic Low, particularly on 22 July, which transported the polluted plume to Europe. On 25 July the Icelandic Low moved northward allowing the air masses to reach the Irish coast. This low level export from the North American east coast in conjunction with a cold front is a classical feature of North American summertime meteorology, and has been shown by, for example, Li et al. (2005) to be an important factor driving summertime pollution export. Warm conveyor belts associated with cold fronts lift pollution from the central and north-eastern US into the free troposphere over Newfoundland, and strong north-eastward outflow takes places at low levels behind the cold front. Li et al. (2005) evaluated the occurrence of such events to be 5 to 7 per month in summer. The transport over the North Atlantic towards Europe is then dependent on the position and strength of the Azores High/Icelandic Low. Guerova et al. (2006) reported that of the export events identified by Li et al. (2005), 3 reached central Europe, with about half at low altitudes. Li et al. (2002) evaluated a higher frequency of low level North American plumes reaching Europe during summer 1994 to 1997. The plume studied here is a case of this kind of pollutant export.

2.2 Chemical composition of the Lagrangian plume matches

Detailed information about the instrumentation on board the aircraft can be found in Fehsenfeld et al. (2006). Since measurements taken by the different aircraft will be used to infer the chemical evolution of the plume, it is important to 
Table 1. Measurements taken during Lagrangian match windows (given in minutes (mn)) as defined in Table 1 of Methven et al. (2006). Data for each window is shown as mean (standard deviation) [number of measurement averaged]. $\mathrm{NO}_{\mathrm{y}}$ values indicated for the first 3 Lagrangian matches are the sum of measured $\mathrm{HNO}_{3}, \mathrm{PAN}, \mathrm{NO}_{2}$ and NO. All measurements indicated in the first column (20 July) are used to initialise the model, except for temperature, water vapour (taken from ECMWF meterological analyses) and aerosol concentrations (see text for details).

\begin{tabular}{|c|c|c|c|c|c|}
\hline & $\begin{array}{l}\text { P3-20/07 } \\
(25 \mathrm{mn})\end{array}$ & $\begin{array}{l}\text { P3-21/07 } \\
(6 \mathrm{mn})\end{array}$ & $\begin{array}{l}\text { P3-22/07 } \\
(23 \mathrm{mn})\end{array}$ & $\begin{array}{l}\text { Falcon-25/07 } \\
(27 \mathrm{mn})\end{array}$ & $\begin{array}{l}\text { Falcon-26/07 } \\
(9 \mathrm{mn})\end{array}$ \\
\hline $\mathrm{CO}$ (ppbv) & $200(30)[1427]$ & $183(12)[361]$ & $181(8)[755]$ & 138 (12) [1621] & $121(1.8)[541]$ \\
\hline $\mathrm{O}_{3}$ (ppbv) & $90(15)[1501]$ & $88(6)[361]$ & $57(6)[781]$ & $44(2.9)[1621]$ & $43(1.5)[541]$ \\
\hline NO (pptv) & $63(25)[1351]$ & $46(7)[361]$ & $32(10)[751]$ & $10(0.002)[1313]$ & 47 (43) [389] \\
\hline $\mathrm{NO}_{2}$ (pptv) & 441 (185) [1351] & $210(51)[361]$ & $115(35)[751]$ & & \\
\hline PAN (pptv) & 649 (331) [650] & $481(134)[181]$ & $268(70)[215]$ & & \\
\hline $\mathrm{HNO}_{3}$ (pptv) & $14400(9500)$ [1236] & 4584 (1032) [361] & $2229(631)[646]$ & & \\
\hline $\mathrm{NO}_{\mathrm{y}}(\mathrm{pptv})$ & $15553(10360)$ & $5307(1383)$ & $2644(742)$ & $175(38)$ & $940(417)$ \\
\hline $\mathrm{C}_{2} \mathrm{H}_{4}$ (pptv) & $21(9)[5]$ & $30[1]$ & $83[2]$ & $100[2]$ & 113 [2] \\
\hline $\mathrm{C}_{2} \mathrm{H}_{6}$ (pptv) & $1291(303)[5]$ & $1170[1]$ & $1205[2]$ & $1075[2]$ & 988 [2] \\
\hline $\mathrm{C}_{2} \mathrm{H}_{2}$ (pptv) & $311(153)[5]$ & $310[1]$ & $266[2]$ & $169[2]$ & $174[2]$ \\
\hline $\mathrm{C}_{3} \mathrm{H}_{6}$ (pptv) & $3(1)[3]$ & $5[1]$ & $26[2]$ & $93[2]$ & $81[2]$ \\
\hline $\mathrm{C}_{4} \mathrm{H}_{1} \mathrm{O}$ (pptv) & $141(75)[5]$ & $103[1]$ & $209[2]$ & $25[2]$ & $62[2]$ \\
\hline $\mathrm{C}_{5} \mathrm{H}_{8}$ (pptv) & $0.2(0.055)[5]$ & $0.4[1]$ & 318 [2] & & \\
\hline $\mathrm{C}_{5} \mathrm{H}_{1} 2$ (pptv) & $77(35)[5]$ & $76[1]$ & $94[2]$ & & \\
\hline $\mathrm{C}_{6} \mathrm{H}_{6}$ (pptv) & $61(41)[5]$ & $58[1]$ & $46[2]$ & & \\
\hline $\mathrm{C}_{7} \mathrm{H}_{8}$ (pptv) & $61(41)[5]$ & $24[1]$ & $20[2]$ & & \\
\hline Methanol (pptv) & 2197 (303) [68] & 2140 (218) [14] & 3360 (513) [39] & & \\
\hline Acetaldehyde (pptv) & 758 (162) [68] & $632(82)[14]$ & 608 (70) [39] & & \\
\hline Acetone (pptv) & $2946(647)[68]$ & 2641 (187) [14] & 3099 (193) [39] & & \\
\hline Aerosols $\left(\mathrm{cm}^{-3}\right)$ & $5474(1646)[1501]$ & $3627(640)[361]$ & $2989(340)[751]$ & & \\
\hline Temp (K) & $293(0.2)[1501]$ & $291(0.3)[361]$ & $295(0.8)[781]$ & $283(0.9)$ [1320] & $282(0.4)[541]$ \\
\hline $\mathrm{H}_{2} \mathrm{O}(\mathrm{g} / \mathrm{kg})$ & $11.8(0.5)[1501]$ & $10.8(0.5)[361]$ & $12.8(0.5)[781]$ & $9.2(0.5)[1621]$ & $7.8(0.3)[541]$ \\
\hline
\end{tabular}

compare these measurements. Several comparison flights were performed between the 4 aircraft involved in the campaign. Overall, the comparison showed that $\mathrm{O}_{3}$ measurements agreed within $2 \mathrm{ppbv}$ and $\mathrm{CO}$ within $3 \mathrm{ppbv}$, for the aircraft used in this study. Comparison of hydrocarbons was more difficult but, where possible, comparison showed good agreement. More details about the comparison flights can be found in Methven et al. (2006) and Fehsenfeld et al. (2006). The general behaviour of the plume evolution is first examined in terms of observed trace gas mean values and correlations. Observed concentrations of $\mathrm{O}_{3}, \mathrm{NO}$ and $\mathrm{NO}_{\mathrm{y}}$ with respect to $\mathrm{CO}$ in the 5 Lagrangian matches are shown in Fig. 2 with average values during the 5 match time windows reported in Table 1. Correlation coefficients, $r$, and slopes were also calculated and provide information about the dispersion of data around the correlation line, and therefore, the quality of the correlation. These results are discussed later in Sect. 4.4 when they are compared to model simulations. (see Table 4).

The first interception of the plume by the P 3 on 20 July showed a highly polluted plume with high values of $\mathrm{CO}$ (200 ppbv) very well correlated $(r=0.91)$ with high values of $\mathrm{O}_{3}(90 \mathrm{ppbv}), \mathrm{NO}_{\mathrm{x}}(500 \mathrm{pptv})$ and very high levels of $\mathrm{NO}_{\mathrm{y}}(15550 \mathrm{pptv})$. Here, $\mathrm{NO}_{\mathrm{y}}$ was mainly in the form of
$\mathrm{HNO}_{3}$ representing approximately $92 \%$ of total $\mathrm{NO}_{\mathrm{y}}$. One day later, $\mathrm{CO}, \mathrm{O}_{3}$ and $\mathrm{NO}_{\mathrm{x}}$ levels slightly decreased, but remained elevated. $\mathrm{HNO}_{3}$ concentrations showed the strongest decrease to only $32 \%$ of the initial value. $\mathrm{O} 3$ and $\mathrm{CO}$ were still highly correlated with a similar slope $(0.51)$ whereas the slope between $\mathrm{NO}$ and $\mathrm{CO}$ decreased strongly even though the two species were still very well correlated $(r=0.85)$. On 22 July, $\mathrm{CO}, \mathrm{NO}_{\mathrm{x}}, \mathrm{PAN}, \mathrm{HNO}_{3}$ and $\mathrm{O}_{3}$ levels decreased and the species are not correlated any more with value of $r$ between 0.14 and 0.3. Moreover, concentrations of the main volatile organic compounds (VOCs) $\left(\mathrm{C}_{2} \mathrm{H}_{6}, \mathrm{C}_{2} \mathrm{H}_{4}, \mathrm{C}_{5} \mathrm{H}_{8}\right.$, $\mathrm{CH}_{3} \mathrm{OH}$, acetone) increased and are higher than on the first Lagrangian sampling. This lack of correlation, as well as the increase in VOCs, could be explained by strong and inhomogeneous mixing with another air mass containing more recent emissions or, as discussed previously, this match appears to be incorrect due to large uncertainties in the calculation of trajectories on this day. Therefore, although comparisons between model results and data on 22 July are shown, the uncertainty surrounding this match should be kept in mind.

The 3 North American interceptions (20, 21 and 22 July) were made close to remote surface sites in New England (Sable Island, Chebogue Point and Appledore Island). Polluted plumes from the New York-Boston region are often 
encountered in this region, as shown by Chen et al. (2007) who estimated that these events occurred $15 \%$ of the time during summer 2004. Comparison of measurements in the Lagrangian match and those analysed by Parrish et al. (1998) at Sable Island and Chebogue Point between 1991-1994, shows that the mean $\mathrm{O}_{3}$ and $\mathrm{CO}$ values as well as the $\mathrm{O}_{3} / \mathrm{CO}$ measured slopes are in the upper range of the surface observations. The aircraft observations were collected away from the surface and were probably subject to less dry deposition of $\mathrm{O}_{3}$. Another factor that can explain the larger $\mathrm{O}_{3} / \mathrm{CO}$ slope is that the $\mathrm{NO}_{\mathrm{x}}$ to $\mathrm{CO}$ emission ratio in the US has changed since the early 1990s. Assuming that the production of $\mathrm{O}_{3}$ is $\mathrm{NO}_{\mathrm{x}}$ limited, then steeper $\mathrm{O}_{3} / \mathrm{CO}$ relationships could be expected in 2004 as suggested by Honrath et al. (2004).

After the plume crossed the North Atlantic it was intercepted on 25 July by the DLR Falcon aircraft off the west coast of Ireland. Lower concentrations of pollutants were measured with mean concentrations of $138 \mathrm{ppbv} \mathrm{CO}$, 44 ppbv $\mathrm{O}_{3}$, and 175 pptv $\mathrm{NO}_{\mathrm{y}}$, which represents only $2 \%$ of the initial $\mathrm{NO}_{\mathrm{y}}$ value. Correlations between species are now very low including the $\mathrm{O}_{3} / \mathrm{CO}$ slope $(-0.03)$. Mean values and slopes can be compared with those measured in North American plumes (identified using a global model) in summer at Mace Head $\left(53^{\circ} \mathrm{N}, 10^{\circ} \mathrm{W}\right)$, on the Irish west coast between 1994 to 1997 by Li et al. (2002). Whilst the average values measured in the Lagrangian plume are within the normal measured range, the $\mathrm{O}_{3} / \mathrm{CO}$ slopes are much lower than the values of 0.2 to 0.4 reported by Li et al. (2002). Reasons for the discrepancies between these measured slopes are analysed further in Sect. 4.4. Note that whilst the $\mathrm{O}_{3}$ concentrations in the match on 25 July are much lower than in the first samplings of the plume, they still represent an increase compared to background in the remote marine environment where the measurements were taken, i.e. 10 to $20 \mathrm{ppbv}$ above average for $\mathrm{O}_{3}$ and 10 to $40 \mathrm{ppbv}$ for $\mathrm{CO}$.

According to Methven et al. (2006), the plume was intercepted a last time by the Falcon over the English Channel on 26 July with $\mathrm{CO}$ and $\mathrm{O}_{3}$ levels slightly lower than the previous day and a negative $\mathrm{O}_{3} / \mathrm{CO}$ slope. As for $\mathrm{NO}$ and $\mathrm{NO}_{\mathrm{y}}$, concentrations are much higher compared to the previous match and $\mathrm{NO}$ and $\mathrm{NO}_{\mathrm{y}}$ levels were even higher than in the first match. This suggests that strong mixing with freshly polluted European air masses may have taken place.

The evolution of this plume in terms of changes in observed concentration changes seems fairly typical with reductions in pollutant levels during transport across the Atlantic and in terms of transport by cold front advection over the US followed by rapid transport towards Europe. Further analysis using a photochemical trajectory model and comparison with measured concentrations in the Lagrangian match segments will provide an insight into the processes which are responsible for the evolution of pollutant levels in this plume.

\section{Modelling}

The Lagrangian photochemical model, CiTTyCAT (CambrIdge Tropospheric TrajectorY model of Chemistry And Transport) has been used to examine the different processes influencing the evolution of trace gases within the plume, and in particular, $\mathrm{O}_{3}, \mathrm{CO}$ and $\mathrm{NO}_{\mathrm{y}}$. CiTTyCAT has been used previsously to examine the origin of polluted layers over the North Atlantic during past campaigns (Wild et al., 1996; Evans et al., 2000). This model also successfully captured the evolution of trace gas concentrations over the North Atlantic in the ICARTT forest fire case identified by Methven et al. (2006) (Real et al., 2007). The model is considered as an isolated air parcel, and run along trajectories calculated using large-scale meteorological analyses. Ninety chemical species are treated in the model including degradation of 14 hydrocarbons using chemical rate data from JPL (2003) and updates discussed in Arnold et al. (2006) for acetone and ethanol. The photolysis scheme used in the runs presented here is based on a 2 -stream multiple scattering scheme (Hough, 1988).

\subsection{Chemical initialisation}

First, the model was used to simulate the evolution of average concentrations in the plume (Sects. 4.1, 4.2.1, 4.3). The model was initialised with concentrations measured in the plume on 20 July by the $\mathrm{P} 3$, and compared with average concentrations measured by the same aircraft on 21 and 22 July as well as by the Falcon on 25 and 26 July. These measured concentrations are indicated in Table 1 . The only specie for which the initial value has not be taken from measurements is methane, with a typical value of $1.8 \mathrm{ppmv}$. In order to characterise the variability in plume concentrations, 3 simulations were carried out: one using mean concentrations measured during the plume match segment on 20 July, and 2 others using the mean concentrations $+(-)$ standard deviation (std). Note that all species are well correlated in the plume making this approach appropriate. Then, in order to extend the analysis the model was initialised across the full range of concentrations in each match segment on 20 July and their inter-relationships (correlations) analysed (Sect. 4.4).

\subsection{Trajectories}

The model was run along a trajectory calculated with the FLEXTRA model (Stohl et al., 1995) using ECMWF ERA40 wind fields. Position, temperature and water vapour used in CiTTyCAT were interpolated from the FLEXTRA trajectory at every CiTTyCAT time-step. All trajectories initialised in the P3 Lagrangian match on 20 July showed approximately the same transport, so the one initialised around 21:20 was chosen (see Fig. 1). This trajectory passes closest to the P3 Lagrangian matches on 21 and 22 July, and the Falcon matches on 25 and 26 July. 

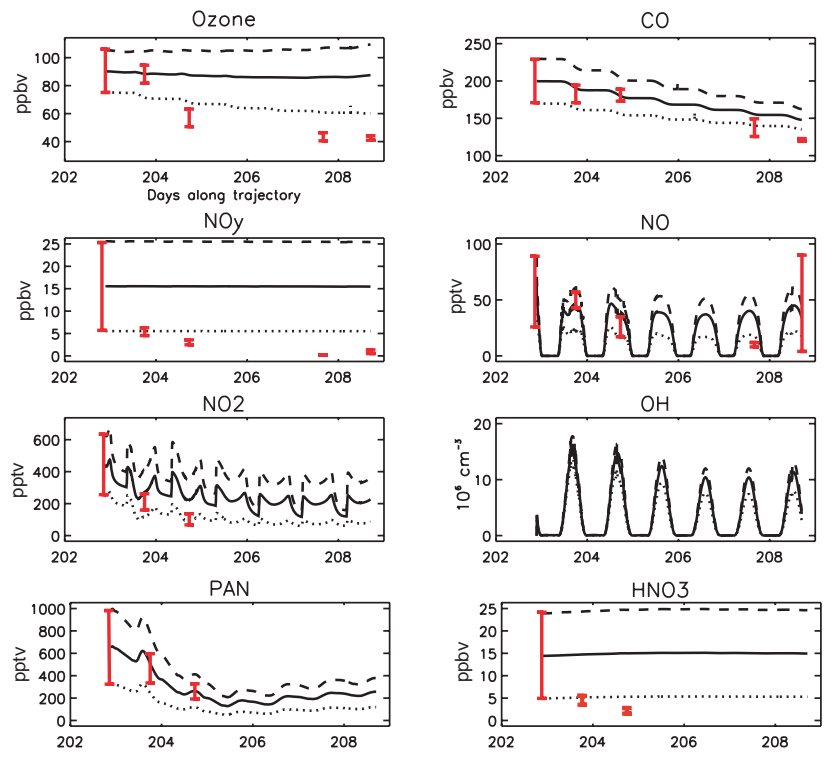

Water vapor

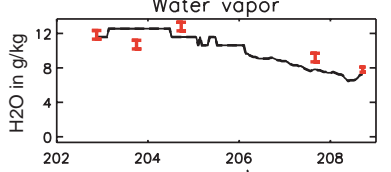

Concentrations, water vapour and temperature
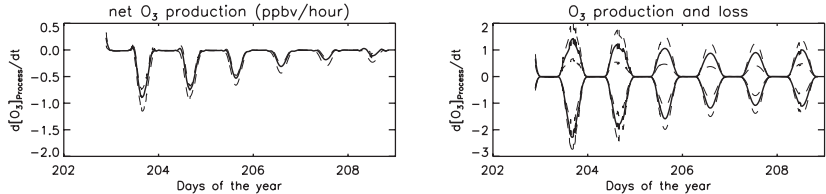

$\left[\mathrm{O}_{3}\right]_{\text {proo }}[\mathrm{NO}] \cdot\left[\mathrm{HO}_{2}\right]$

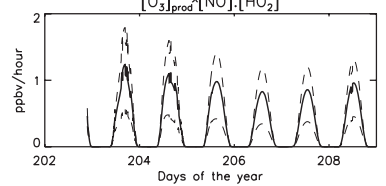

$\left[\mathrm{O}_{3}\right]_{\text {proot }}[\mathrm{NO}] \cdot\left[\mathrm{RO}_{2}\right]$
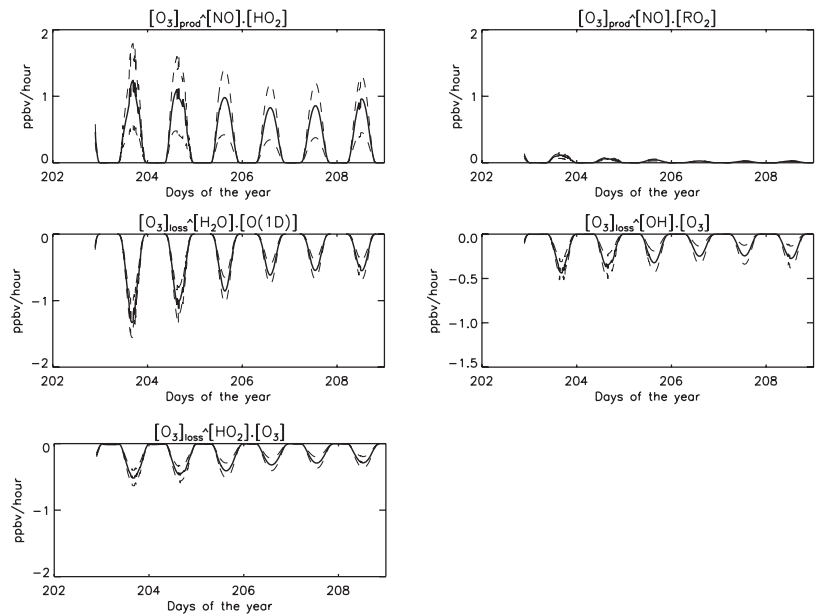

Hourly $\mathrm{O}_{3}$ production and destruction terms

Fig. 4. Temporal evolution (Julian days) of (a) simulated concentrations, and (b) simulated $\mathrm{O}_{3}$ production and destruction rates, initialised with mean (continuous lines), mean - std (dotted line) and mean +std (dashed lines) concentrations taken from the P3 data during the match segments on 20 July. Downwind mean and std data observed during the plume match segments are represented as red vertical lines (see text for details).

\subsection{Representation of physical phenomena}

Wet and dry deposition as well as mixing can be included in the model. Dry deposition is simulated when the air parcel is in the BL using a velocity parameter which depends on surface type and on the height of the BL. The BL was defined climatologically from GEOS-1 meteorological data (Schubert et al., 1993). The original wet deposition scheme is a simple scheme using a lifetime for soluble species. More details about the model can be found in Wild et al. (1996) and Evans et al. (2000). The model was first run with only photochemical processes (Sect. 4.1) in order to study the chemical evolution of the plume in the absence of other processes. Then, since the plume was transported at low altitudes, and sometimes in the BL, runs were made including dry deposition (Sect. 4.2.1). GOES METEOSAT satellite images (see Fig. 3) indicate the presence of clouds, on certain occasions, in the same location as the plume, especially over the North American coast. Moreover, the strong decrease in $\mathrm{HNO}_{3} \mathrm{ob}-$ served in the plume is likely to be the result of wet deposition since $\mathrm{HNO}_{3}$ is highly soluble. For this reason, runs were also carried out including wet deposition. In addition, a new scheme was implemented based on precipitation rates from ECMWF (Sect. 4.2.2). Note that aerosol levels in the plume were high initially but dropped between 20 and 22 July from about $5.5 \times 10^{3}$ particles per $\mathrm{cm}^{-3}$ to $3.0 \times 10^{3} \mathrm{~cm}^{-3}$ which may also indicate that deposition was active, even if other mechanisms (dilution, coagulation) could also explain this decrease. Heterogeneous reactions were not included in the majority of simulations discussed here. However, the sensitivity of results to $\mathrm{N}_{2} \mathrm{O}_{5}$ hydrolysis on aerosols was examined and is discussed in Sect. 4.2.3. Finally, mixing between the plume and surrounding air masses was also considered (Sect. 4.3).

\section{Results}

\subsection{Chemistry-only simulations}

Simulated concentrations of $\mathrm{CO}, \mathrm{O}_{3}, \mathrm{NO}, \mathrm{NO}_{2}, \mathrm{HNO}_{3}$ and PAN for the model runs initialised with mean, mean + std and mean - std concentrations measured in the P3 Lagrangian match on 20 July are shown in Fig. 4 together with simulated $\mathrm{O}_{3}$ production and destruction terms. Water vapour and temperature data interpolated along the trajectory from ECMWF analyses are also shown. These results include only changes due to photochemical processes in the model. 


\subsubsection{Simulated plume characteristics}

The modelled chemical evolution of the plume shows two interesting features. Firstly, despite high levels of water vapour, high concentrations of $\mathrm{NO}, \mathrm{NO}_{2}, \mathrm{HNO}_{3}$ and $\mathrm{O}_{3}$ are maintained in the plume whereas PAN levels decrease rapidly due to high temperatures. Analysis of $\mathrm{O}_{3}$ production and destruction terms shows that $\mathrm{O}_{3}$ destruction due to water vapour is important, but is almost balanced by photochemical $\mathrm{O}_{3}$ production. Sensitivity tests will help to understand the origin of this high $\mathrm{O}_{3}$ production (see Sect. 4.1.3). The second interesting feature is the high oxidising capacity of the plume. In these chemistry only simulations, $\mathrm{OH}$ levels remain high during the entire run with mean values of $4 \times 10^{6}$ molecs. $\mathrm{cm}^{-3}$ and peaks around $15 \times 10^{6}$ molecs. $\mathrm{cm}^{-3}$ around noon. This can be mainly explained by high water vapour, due to the low altitude of the plume and high $\mathrm{O}_{3}$ concentrations.

One of the main impacts of this high oxidising capacity is the strong photochemical destruction of $\mathrm{CO}$, which decreases by about $50 \mathrm{ppbv}$ in 6 days. $\mathrm{CO}$ is often considered as a pollution tracer, not really affected by chemical loss over a period of 10 days or less, with a strong decrease in $\mathrm{CO}$ usually attributed to dilution and mixing. Here, assuming no other loss processes, $\mathrm{CO}$ decreased by $25 \%$ solely as a result of chemical destruction. This would imply that for this plume, transported at low altitudes, the $\mathrm{CO}$ chemical lifetime is about 20 days. This value can be compared with a value of 30 days for the global mean $\mathrm{CO}$ lifetime during summer.

\subsubsection{Comparison of measured and simulated concentra- tions}

The general evolution of measured PAN and $\mathrm{CO}$ values are reproduced in the model solely with chemical processing suggesting an important role for photochemistry in this case although $\mathrm{CO}$ is still overestimated after 6 days and PAN data were only available from the $\mathrm{P} 3$. Measured $\mathrm{NO}$ and $\mathrm{NO}_{2}$ values are generally overestimated by the mean simulations, and are more represented by the mean - std simulation. $\mathrm{O}_{3}$ values are overestimated by more than 40 ppbv after 5 days but the strongest difference is found between simulated and measured $\mathrm{HNO}_{3}$ with average modelled concentrations $13 \mathrm{ppbv}$ higher after 3 days. These differences suggest that other processes such as deposition, heterogeneous loss on aerosols or mixing may also be important. Unfortunately, measurements of other species like $\mathrm{H}_{2} \mathrm{O}_{2}$ or $\mathrm{HCHO}$ for the three $\mathrm{P} 3$ flights were not available to provide further tests of the model results discussed in the next sections. Concerning $\mathrm{OH}$, model results are the same order of magnitude as those calculated by Warneke et al. (2004) using a box model initialised with measurements from a research ship along the New England coast, i.e. in the same region as the Lagrangian plume during the first 3 days, albeit at a lower altitude. However, the peak noon values simulated here are higher than those measured, for example, in the Los Angeles basin by George et al. (1999) $\left(7 \times 10^{6}\right.$ molecs. $\left.\mathrm{cm}^{-3}\right)$, and by Ehhalt and Roher (2000) at a rural German site $\left(12 \times 10^{6}\right.$ molecs. $\left.\mathrm{cm}^{-3}\right)$. Measured $\mathrm{JO}^{1} \mathrm{D}$ and $\mathrm{JNO}_{2}$ during the 3 first Lagrangian samplings are in good agreement with simulated values (not shown). In these chemistry only runs the model underestimates several VOCs: $\mathrm{C}_{2} \mathrm{H}_{2}, \mathrm{C}_{2} \mathrm{H}_{6}, \mathrm{C}_{4} \mathrm{H}_{10}, \mathrm{C}_{2} \mathrm{H}_{4}$ and $\mathrm{C}_{3} \mathrm{H}_{6}$ are underestimated by $70,140,20,110$ and 90 pptv respectively on the 25 July. Concerning water vapour and temperature, the difference between measured values and those interpolated from ECMWF analyses along the trajectory is always less than $20 \%$ for water vapour and $4 \mathrm{~K}$ for temperature. Therefore, in these runs which only take chemical processes into account, the overestimation in $\mathrm{O}_{3}$ leads to an overestimation in $\mathrm{OH}$ and therefore other processes are also playing an important role as will be discussed in the following sections.

\subsubsection{Sensitivity tests}

In order to better understand photochemical processing in the plume and possible reasons for the differences between simulated and observed $\mathrm{O}_{3}$, two sensitivity tests were performed. Firstly, initial $\mathrm{HNO}_{3}$ concentrations were reduced to zero (SnoHNO $\mathrm{H}_{3}$ ) in order to study the role of $\mathrm{HNO}_{3}$ in the net production of $\mathrm{O}_{3}$ during transport. Secondly, a cloud with an optical depth of 5 (value of the mean cloud optical depth observed globally by Rossow and Schiffer, 1991) was simulated just above the plume (S-CLOUD) in order to examine the maximum effect of a cloud layer on photolysis rates inside the plume. The S-CLOUD simulation is representative of a maximum effect because clouds were not present during the entire transport over the North Atlantic as shown by the GOES-METEOSAT satellite images. In particular, clouds were not present during the match periods when, as noted previously, modelled photolysis rates agree well with the measurements. The chosen optical depth is also relatively high for non-convective clouds. In both cases simulations were initialised with mean values measured in the plume. Results of these sensitivity tests are shown in Fig. 5.

Results of the run $\mathrm{S}-\mathrm{noHNO}_{3}$ clearly show that the maintenance of high $\mathrm{O}_{3}$ levels in the chemistry-only simulation is mainly due to $\mathrm{HNO}_{3}$ photolysis. Indeed after 6 days, $\mathrm{O}_{3}$ concentrations in the $\mathrm{S}_{-}$noHNO 3 simulation are lower than the reference simulation by about $35 \mathrm{ppbv}$, and the mean net $\mathrm{O}_{3}$ production decreases by $70 \%$. This leads to a reduction in the oxidising capacity of the plume $(\mathrm{OH}$ is reduced by $30 \%$ ) leading to higher simulated $\mathrm{CO}$ concentrations (20 to $30 \mathrm{ppbv}$ ). It shows that when initial $\mathrm{HNO}_{3}$ concentrations are high, the quantity of $\mathrm{HNO}_{3}$ available for photolysis becomes non-negligible. In the absence of loss processes, $\mathrm{HNO}_{3}$, which acts initially as a reservoir, then releases $\mathrm{NO}_{2}$ during long-range transport. Neuman et al. (2006) also measured high $\mathrm{HNO}_{3}$ in several other plumes during ICARTT, some of them as far as $1000 \mathrm{~km}$ downwind from source regions and showed the importance of $\mathrm{HNO}_{3}$ in the production of $\mathrm{O}_{3}$ in 

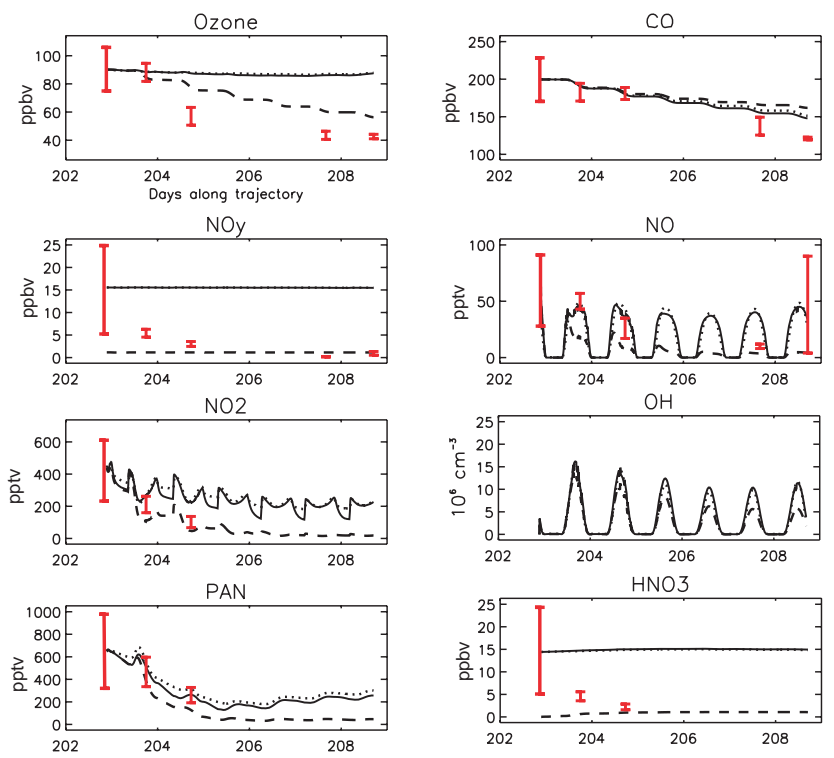

Fig. 5. Concentration versus time (Julian days) from modelled reference simulation (continuous lines), $\mathrm{S}-\mathrm{noHNO} 3$ simulation (dashed lines) and S-CLOUD simulation (dotted lines) (see text for details).

plumes rich in $\mathrm{HNO}_{3}$. However, this strong role played by $\mathrm{HNO}_{3}$ assumes a weak influence of wet deposition.

Concerning the S-CLOUD simulation, the presence of cloud above the plume is responsible for a reduction in photolysis rates $\left(-9 \%\right.$ for $\mathrm{JNO}_{2}$ and $-7 \%$ for $\left.\mathrm{JO}^{1} \mathrm{D}\right)$ in these runs. Since there are compensating effects both $\mathrm{O}_{3}$ production and destruction are reduced and so the presence of cloud does not modify $\mathrm{O}_{3}$ concentrations by much and cannot explain the difference between observed and simulated $\mathrm{O}_{3}$ values. This reduction in $\mathrm{JO}^{1} \mathrm{D}$ leads to a decrease in the oxidising capacity of the plume by a few percent and therefore to less $\mathrm{CO}$ destruction.

\subsection{Chemistry and deposition simulations}

\subsubsection{Dry deposition}

Results of model runs including photochemistry plus dry deposition are shown in Fig. 6 (orange lines). Dry deposition is simulated in the model when the plume is in the BL, i.e. about $15 \%$ of the time. The BL definition in the model is climatologically defined, and so, not specifically calculated for the days of the study. The modelled BL heights for the Lagrangian matches were checked by plotting vertical profiles of water vapour observed by the P3 aircraft around the Lagrangian matches. The profiles in Fig. 7 show that every time the aircraft was over ocean (profiles a and part of profile b), the BL height was less than $0.4 \mathrm{~km}$ and so the plume was above the BL, whereas over land, the BL height was between 1 and $1.5 \mathrm{~km}$ and the plume was in the BL. This corresponds
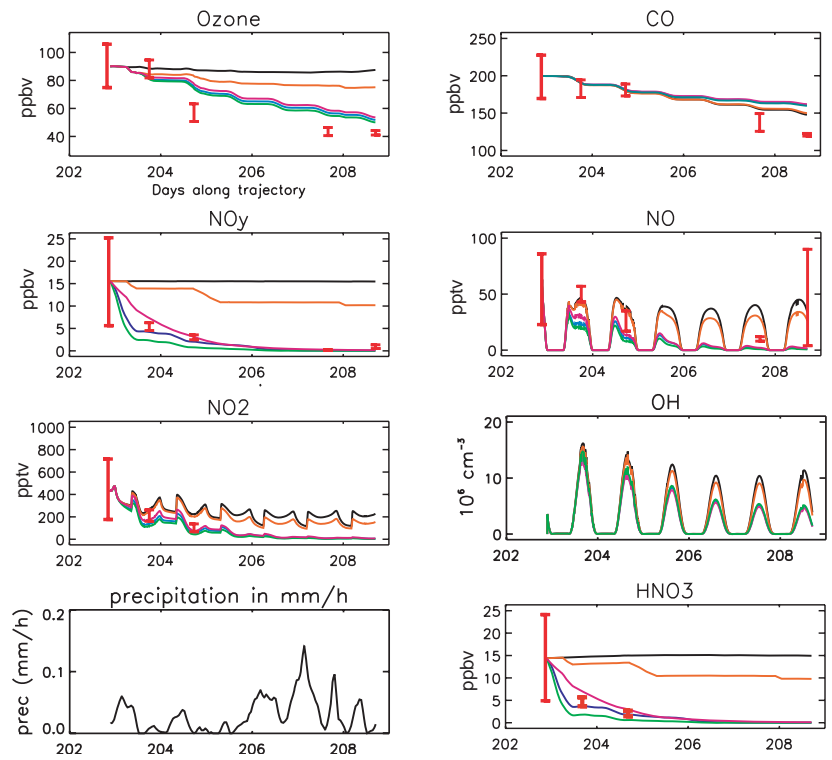

Fig. 6. Modelled concentrations versus time (Julian days) without deposition (black lines), with dry deposition only (orange lines), with S-WET1 wet deposition+dry deposition (pink lines), with SWET2 wet deposition +dry deposition (bllue lines), and with SWET3 wet deposition+dry deposition (green lines). Precipitation interpolated from ECMWF precipitation rates (sum over total column) are also shown in lower left panel.

well to the model simulation which has no dry deposition during the 2 first Lagrangian samplings over sea on 20 and 21 July and dry deposition active on 22 July when the trajectory passed over land. Inclusion of dry deposition in the simulations leads to decreases of 8 and $20 \%$ in $\mathrm{O}_{3}$ and $\mathrm{HNO}_{3}$, respectively. However, it is clear that dry deposition alone cannot explain the observed decrease in either $\mathrm{HNO}_{3}$ or $\mathrm{O}_{3}$ in this plume. For a plume travelling at lower altitude and spending more time in the BL, a much more important impact of dry deposition could be expected. The results are also sensitive to the definition of the BL height and to positional errors in the trajectories as already discussed in Sect. 2.

\subsubsection{Wet deposition}

As noted already, satellite images and the strong decrease of $\mathrm{HNO}_{3}$ levels in the plume suggest that wet deposition was active during the transport of this plume away from source regions. In the basic model, wet deposition is parametrised using a local constant loss rate, $r$ (s-1) (run S-WET1). In this study, two new schemes were implemented linking wet deposition to more realistic column integrated precipitation rates, $p\left(\mathrm{~mm} \mathrm{~s}^{-1}\right)$ taken from ECMWF analyses. The first scheme (S-WET2) is based on Walton et al. (1988) who introduced a wet deposition coefficient, $S$, such that $r=S \times p$. For a very soluble gas, such as $\mathrm{HNO}_{3}$, Penner et al. (1991) suggested values of $\mathrm{S}$ equal to $2.4 \mathrm{~mm}^{-1}$ for stratiform precipitation, 


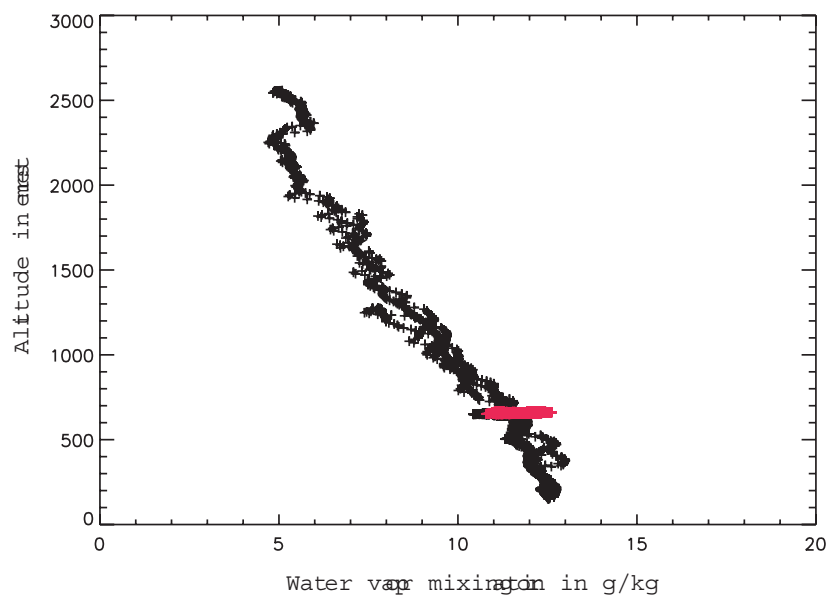

20 July from $20 \mathrm{~h} 30$ to $21 \mathrm{~h} 30$

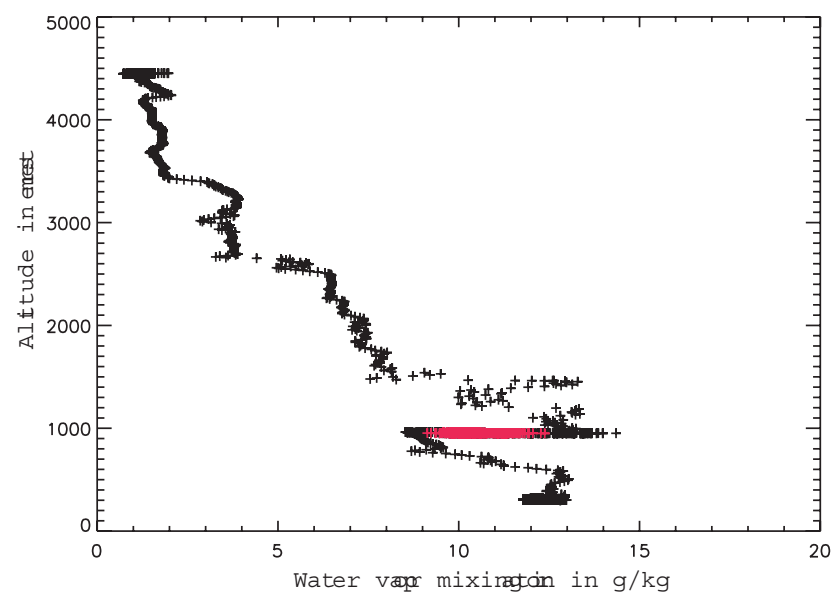

21 July from $07 \mathrm{~h} 30$ to $18 \mathrm{~h} 30$

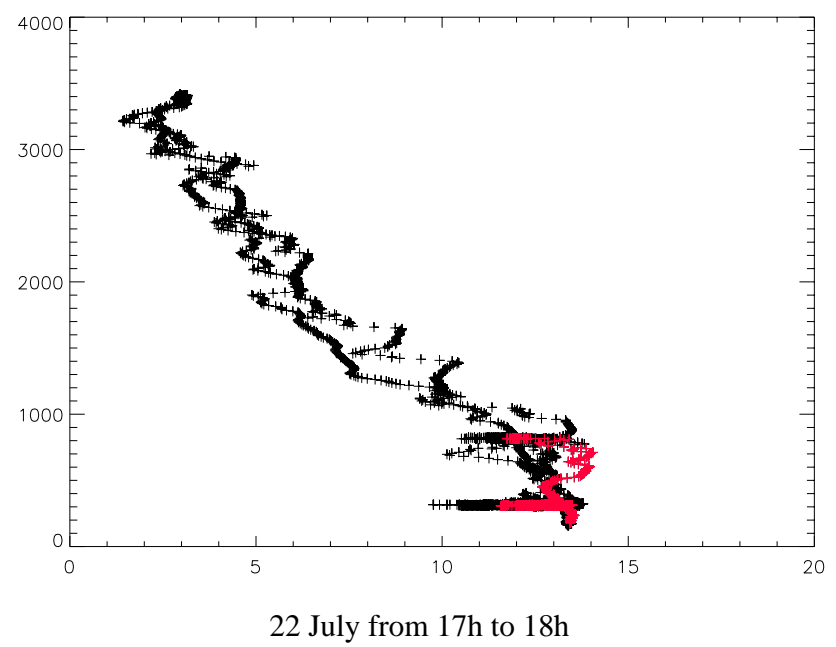

Fig. 7. Vertical water vapour profiles measured by the P3 close to the Lagrangian matches on 20, 21 and 22 July 2004. Measurements made in the Lagrangian matches are coloured in red.

and $4.7 \mathrm{~mm}^{-1}$ for convective precipitation. The second scheme (S-WET3) uses a classical formula for the simulation of wet loss of a very soluble specie, $r=p / L$ were $L$ represents the quantity of condensed water integrated over the tropospheric column (mm). Wentz and Spencer (1998) estimated a value of $L$ from a satellite study using $0.18 \times\left(1+(H p)^{0.5}\right)$, where $H$ is the rain column depth, taken as equal to $3 \mathrm{~km}$ at mid latitudes. In this formulation there is no distinction between convective and stratiform precipitation. These two formulations apply to very soluble gases like $\mathrm{HNO}_{3}$. To evaluate $r$ for other trace species $\left(\mathrm{NO}_{3}, \mathrm{~N}_{2} \mathrm{O}_{5}, \mathrm{HO}_{2} \mathrm{NO}_{2}, \mathrm{HO}_{2}\right.$, $\mathrm{H}_{2} \mathrm{O}_{2}, \mathrm{HCHO}, \mathrm{C}_{2} \mathrm{H}_{5} \mathrm{OO}, \mathrm{C}_{2} \mathrm{H}_{5} \mathrm{OOH}, \mathrm{HONO}$ ) in the model, results from Crutzen and Lawrence (2000) have been used. They determined a factor $\alpha_{\text {spec }}$ that varies from 0 for insoluble gases to 1 for very soluble gases, and depends on the Henry's Law coefficient (see Table 2) in such way that the new local loss frequency, $r *=r \times \alpha_{\text {spec }}$ is calculated. Note that none of these wet deposition schemes makes a distinc- tion between precipitation within and below clouds since this information was not available from ECMWF for this study.

Results from the runs including dry and wet deposition, SWET1 (pink lines), S-WET2 (blue lines) and S-WET3 (green lines) are shown in Fig. 6 together with precipitation rates simulated by ECMWF along the trajectory. It can be noted that the Lagrangian matches correspond to periods with very low precipitation which is coherent with the fact that modelled photolysis rates agree well with the measurements in runs with no clouds.

In order to compare the rate of decrease of $\mathrm{HNO}_{3}$, a parameter $\tau_{1 / 2}$ can be defined as $\tau_{1 / 2}=\log (2) \times \frac{1}{r_{\text {mean }}}$ where $r_{\text {mean }}$ is the mean local loss frequency calculated along the trajectory. This parameter is the half-life of a trace gas corresponding to an exponential decrease in its concentration. It is equal to 19,15 and $6 \mathrm{~h}$, respectively, for simulations dry + S-WET1, dry + S-WET2 and dry + S-WET3. Results from the run dry $+\mathrm{S}$-WET3 underestimates $\mathrm{HNO}_{3}$ concentrations 
Table 2. $\alpha_{\text {spec }}$ values (coefficient factor apply to the wet loss frequency to take into account solubility of species) as a function of effective Henry's Law coefficient $(H f)$ (see text).

\begin{tabular}{lllllll}
\hline$H f$ & $H f<10^{3}$ & $10^{3}<H f<10^{4}$ & $10^{4}<H f<10^{5}$ & $10^{5}<H f<10^{6}$ & $10^{6}<H f<10^{8}$ & $H f>10^{8}$ \\
\hline$\alpha_{\text {spec }}$ & 0 & 0.15 & 0.5 & 0.85 & 0.95 & 1 \\
\hline
\end{tabular}

by about $2.5 \mathrm{ppbv}$ compared to the measurements on 21 July. Results from the dry +S-WET1 and dry +S-WET2 simulations compare better with the data even if $\mathrm{HNO}_{3}$ is underestimated in the dry $+\mathrm{S}$-WET2 run by about $1.5 \mathrm{ppbv}$ on 21 July, and overestimated in the dry +S-WET1 run by the same order of magnitude.

Overall, results using ECMWF precipitation rates (SWET2 or S-WET3) do not give better results than S-WET1 even if these schemes are more realistic. Here, and in the following sections, results using wet deposition scheme, SWET2, have been used because it gives better agreement with $\mathrm{HNO}_{3}$ measurements than S-WET3, and is more physically realistic that $\mathrm{S}-\mathrm{WET} 1$. Since $\mathrm{NO}_{\mathrm{y}}$ is mainly made up of $\mathrm{HNO}_{3}$, the half-life of $\mathrm{HNO}_{3}$ with the S-WET2 scheme can be compared with the one estimated by Stohl et al. (2002) for $\mathrm{NO}_{\mathrm{y}}$ during the 1997 North Atlantic Regional Experiment (NARE) also off the north-east coast of North America. In that study $\tau_{1 / 2}$ was estimated to be around $40 \mathrm{~h}$, a factor of 2 slower than in the case studied here. This can be partly explained by the fact that air masses selected by Stohl et al. (2002) were rapidly exported out of the BL by frontal warm conveyor belts, and so only subject to wet deposition. The plume studied here stayed in the BL during the first few days, and was therefore influenced by both wet and dry deposition.

Overall results from the chemistry and dry/wet deposition runs are closer to the measurements than the chemistry only run. The impact of wet deposition is not only important for $\mathrm{HNO}_{3}$ but also for species that are insoluble but dependent on $\mathrm{HNO}_{3}$ concentrations. Modelled $\mathrm{NO}_{\mathrm{x}}$ is now almost equal to zero after 6 days due to lower $\mathrm{HNO}_{3}$ photolysis leading to a reduction in $\mathrm{O}_{3}$ production rates which decrease by $60 \%$ due to the impact of wet deposition. This leads to better agreement with the observations, although $\mathrm{O}_{3}$ is still overestimated by 5 to $10 \mathrm{ppbv}$ on 25 and 26 July and NO underestimated by 10 to 20 pptv. OH is reduced by $27 \%$ when wet deposition is included leading to a slight increase in CO lifetime from 20 to 23 days. $\mathrm{CO}$ is still overestimated compared to the data suggesting that dilution and mixing were also important as will be seen in the next section. Not only $\mathrm{HNO}_{3}$ is wet deposited but also soluble species like $\mathrm{H}_{2} \mathrm{O}_{2}$ or $\mathrm{CH}_{2} \mathrm{O}$. A test simulation has been conducted where only $\mathrm{HNO}_{3}$ was wet deposited. Results are similar to those where all soluble species are deposited with less than $2 \%$ differences. This confirms that the simulated changes when wet deposition is included are almost exclusively due to $\mathrm{HNO}_{3}$ removal.

\subsubsection{Impact of $\mathrm{N}_{2} \mathrm{O}_{5}$ hydrolysis}

In the runs discussed in the previous sections, heterogeneous loss of trace species on aerosols was not taken into account in the model. This can be important for $\mathrm{N}_{2} \mathrm{O}_{5}$ which can be converted to $\mathrm{HNO}_{3}$ through heterogeneous reactions. At night the conversion of $\mathrm{NO}_{\mathrm{x}}$ into $\mathrm{N}_{2} \mathrm{O}_{5}$ becomes the major $\mathrm{NO}_{\mathrm{x}}$ sink and if no hydrolysis occurs $\mathrm{N}_{2} \mathrm{O}_{5}$ decomposes back into $\mathrm{NO}_{\mathrm{x}}$ the following day. However, heterogeneous reaction may be difficult to simulate as there are still some uncertainties on the reaction probability value and its dependence on water vapour and temperature. Here, the sensitivity of results to heterogeneous loss of $\mathrm{N}_{2} \mathrm{O}_{5}$ has been examined using a parametrisation from Mozurkevich and Calvert (1988). Loss rates were calculated based on recommended temperature and relative humidity dependent uptake coefficient and measurement derived surface aerosol densities using observations made in the plume on 20 July. Since wet deposition and dilution may decrease aerosol density, an exponential decrease was applied with a half life time of 2 days in order to mimic the decrease in aerosol number between 20 and 21 July. Results of these simulations with and without deposition are represented Fig. 8. When no wet or dry deposition is included, the impact of $\mathrm{N}_{2} \mathrm{O}_{5}$ hydrolysis on $\mathrm{NO}_{\mathrm{x}}$ and $\mathrm{O}_{3}$ concentrations is important (see Fig. 8a). $\mathrm{O}_{3}$ concentrations decrease by about 5-6 ppbv over 6 days and $\mathrm{NO}_{\mathrm{x}}$ are lower by almost $50 \%$. Whilst this leads to better agreement with $\mathrm{NO}_{\mathrm{x}}$ measurements, $\mathrm{HNO}_{3}$ is still overestimated by almost $10 \mathrm{ppbv}$ indicating that loss by wet deposition is a dominating factor in this case. In runs including wet deposition (see Fig. 8b) the impact of including or not including $\mathrm{N}_{2} \mathrm{O}_{5}$ hydrolysis on $\mathrm{O}_{3}, \mathrm{NO}$ and $\mathrm{NO}_{2}$ levels is less important even if $\mathrm{NO}_{\mathrm{x}}$ are significantly reduced with hydrolysis (by about $20 \%$ ). This is due to the strong deposition of $\mathrm{HNO}_{3}$ and therefore the strong reduction of $\mathrm{NO}_{\mathrm{x}}$ in the first couple of days. Overall $\mathrm{N}_{2} \mathrm{O}_{5}$ hydrolysis leads to further underestimation of $\mathrm{NO}$ and $\mathrm{NO}_{2}$ concentrations. In the following simulations, $\mathrm{N}_{2} \mathrm{O}_{5}$ hydrolysis is not taken into account.

\subsection{Role of mixing}

\subsubsection{Mixing parametrisation}

In the previous runs the plume was considered isolated from the background. In the real atmosphere, plumes are subject to stirring by large-scale winds and mixing by processes such as turbulence. Mixing entrains surrounding air masses leading 

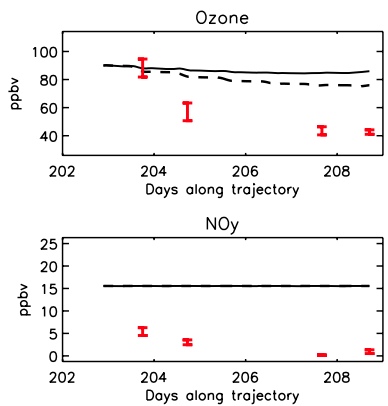

$\mathrm{NO} 2$

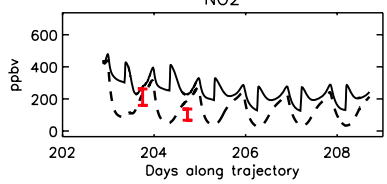

Without deposition

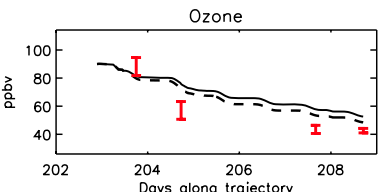

NOY

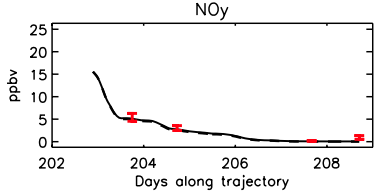

NO2
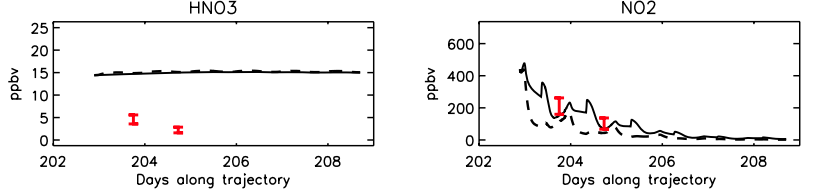
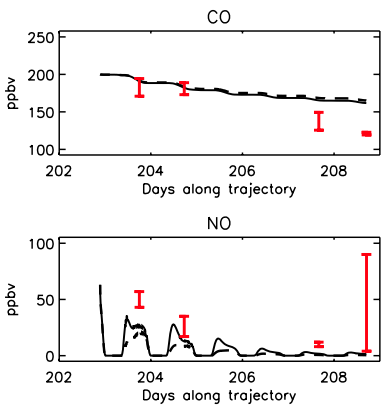

$\mathrm{HNO} 3$

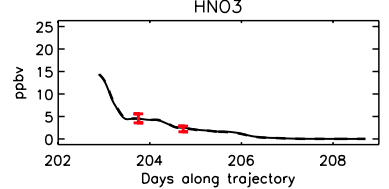

With deposition

Fig. 8. Modelled concentrations versus time (Julian days) for reference runs (continuous lines) and runs including hydrolysis of $\mathrm{N}_{2} \mathrm{O}_{5}$ (dashed lines) (a) without deposition (b) with wet and dry deposition.

Table 3. Measured concentrations in the vicinity of the Lagrangian plume used as background concentrations for the mixing simulations (see text for details).

\begin{tabular}{lllll}
\hline Time windows & $\mathrm{CO}$ (ppbv) & $\mathrm{O}_{3}$ (ppbv) & $\mathrm{NO}_{\mathrm{y}}$ (pptv) & $\mathrm{NO}$ (pptv) \\
\hline 21 h, 20 July-12 h, 21 July & 182 & 73 & 6109 & 120 \\
12 h, 21 July-12 h, 22 July & 184 & 78 & 4085 & 55 \\
12 h, 22 July-12 h, 23 July & 170 & 65 & 3502 & 42 \\
12 h, 23 July-22 h, 25 July & 90 & 30 & 150 & 10 \\
22 h, 25 July-26, July & 130 & 47 & 5910 & 1160 \\
\hline
\end{tabular}

to changes in plume concentrations. In the model, mixing is treated as a simple linear relaxation (Evans et al., 2000) with an exponential decay of plume concentrations towards background concentrations using a typical time scale, $\tau$-mix. Due to the Lagrangian aspect of this work, measurements made in the vicinity of the plume during the 5 match segments can be used to estimate background concentrations. This method was already successfully applied to the to the forest fire case discussed in (Real et al., 2007).

Therefore, measurements of $\mathrm{NO}, \mathrm{O}_{3}, \mathrm{CO}, \mathrm{C}_{2} \mathrm{H}_{4}, \mathrm{C}_{2} \mathrm{H}_{6}$, $\mathrm{C}_{2} \mathrm{H}_{2}, \mathrm{C}_{3} \mathrm{H}_{6}, \mathrm{C}_{4} \mathrm{H}_{10}, \mathrm{NO}_{\mathrm{y}}$ (for background of the last 3 days) and $\mathrm{PAN}, \mathrm{HNO}_{3}, \mathrm{C}_{5} \mathrm{H}_{12}, \mathrm{C}_{6} \mathrm{H}_{6}, \mathrm{C}_{7} \mathrm{H}_{8}$, methanol, acetaldehyde, acetone (for background of the first 3 days) made in plume vicinity were used as background concentrations (see Table 3 for $\mathrm{NO}, \mathrm{NO}_{\mathrm{y}}, \mathrm{O}_{3}$ and $\mathrm{CO}$ concentrations.

During the first 3 days, the so-called background concentrations were polluted. Indeed, pollutant concentrations measured by the P3 on 20, 21 and 22 July between the ground and $2 \mathrm{~km}$ were always elevated over the Gulf of Maine and Nova Scotia. Measurements of PAN, $\mathrm{HNO}_{3}, \mathrm{C}_{5} \mathrm{H}_{12}, \mathrm{C}_{6} \mathrm{H}_{6}, \mathrm{C}_{7} \mathrm{H}_{8}$, methanol, acetaldehyde, acetone as well as $\mathrm{NO}, \mathrm{NO}_{\mathrm{y}}, \mathrm{O}_{3}$ and $\mathrm{CO}$ observation in the plume vicinity were used to constrain background concentrations during the first 3 days (see Table 3). Between 22 and 25 July, the plume left the North American east coast and travelled over the ocean when it can be considered that the plume was no longer surrounded by polluted air masses but by marine air masses. For this reason, air masses typical of marine air, measured in proximity to the plume on 25 July, were used to characterise background air masses from 23 to 25 July. Finally, high concentrations of NO (up to $1.5 \mathrm{ppbv}$ ) and $\mathrm{NO}_{\mathrm{y}}$ (up to $6 \mathrm{ppbv}$ ) were measured on 26 July just after the sampling of the plume. These values were used to define background values. These $\mathrm{NO}_{\mathrm{y}}$ rich air masses were relatively poor in $\mathrm{CO}$ and $\mathrm{O}_{3}$ but rich in $\mathrm{NO}$ suggesting that they could be due to local ship emissions in the English Channel (Corbett and Koehler, 2003). However, back trajectories also show transport from southern England suggesting a possible urban source.

With regard to the determination of $\tau$-mix, changes in $\mathrm{CO}$ are often used since it is usually considered as a good tracer of air mass transport over time periods of several days. However, in this case, the decrease in CO is strongly influenced by photochemical processes, and is not a very good indicator of dilution and mixing. Arnold et al. (2006) evaluated a $\tau$ of 10 
days, with a method based on hydrocarbon ratio changes, for plumes crossing the North Atlantic during the ICARTT campaign. The same $\tau$ was used here except for the last day when a faster mixing rate was used ( $\tau=2$ days) when plume entered the European BL in order to represent the strong increase in $\mathrm{NO}$ and $\mathrm{NO}_{\mathrm{y}}$ observed on 26 July. It should be noted that $\mathrm{CO}$ and $\mathrm{O}_{3}$ concentrations measured on 26 July in the vicinity of the plume are very close to the levels in the plume itself and so the plume was not easily distinguishable from the background based on these measurements alone. The mixing time-scale of 10 days, used during the first 5 days, implies slightly weaker mixing rates compared to previous studies (Real et al., 2007; Price et al., 2004). This could be related to the plume remaining relatively intact during transport due to strongly converging low level winds, and the fact that the plume was decoupled from the marine BL during transport making mixing and dilution less important in this case. However, the impact of the choice of mixing rate is also dependent on the choice of background concentrations during transport. For example, applying a stronger mixing rate during the first 3 days would only change the results slightly because the background concentrations are not very different from those in the plume and the entire Nova Scotia/Gulf of Maine region was influenced by pollution during this period. The choice of mixing rates is case specific and cannot necessarily be taken as representative of mixing rates in the lower troposphere.

\subsubsection{Results: chemistry, deposition and mixing}

Model results including chemistry, deposition and mixing processes are shown in Fig. 9. During the first 5 days, mixing does not change concentrations very much, mainly because of the low mixing rate used, and the fact that background concentrations used during the first 3 days are not very different from those in the plume. Overall, there is now good agreement between the model results and the measurements for the entire period except for 22 July further supporting the hypothesis that this match is not truly Lagrangian. The agreement on with the data on 21 July is generally good although $\mathrm{NO}$ is still underestimated by about $20 \mathrm{pptv}$. There is good agreement with $\mathrm{CO}$ and $\mathrm{O}_{3}$ data in the Lagrangian match on 25 July, with further decreases of 13 and 6 ppbv compared to the runs without mixing, respectively, but NO is still underestimated. However, observed NO is very low by this time and close to the detection limit of the instrument. Modelled concentrations are also closer to the data on 26 July, especially for NO which is mixed with higher background concentrations. These differences are analysed further in the following section using $\mathrm{O}_{3} / \mathrm{CO}$ and $\mathrm{NO}_{\mathrm{y}} / \mathrm{CO}$ correlations.

Concerning modelled $\mathrm{OH}$ values, the runs including deposition and mixing lead to a reduction in $\mathrm{OH}$ of $25 \%$ with an average value of $3 \times 10^{6}$ molecs. $\mathrm{cm}^{-3}$ over the period from the 21 to 25 July, with peak noon values of $14 \times 10^{6}$ molecs. $\mathrm{cm}^{-3}$. These values are still slightly higher
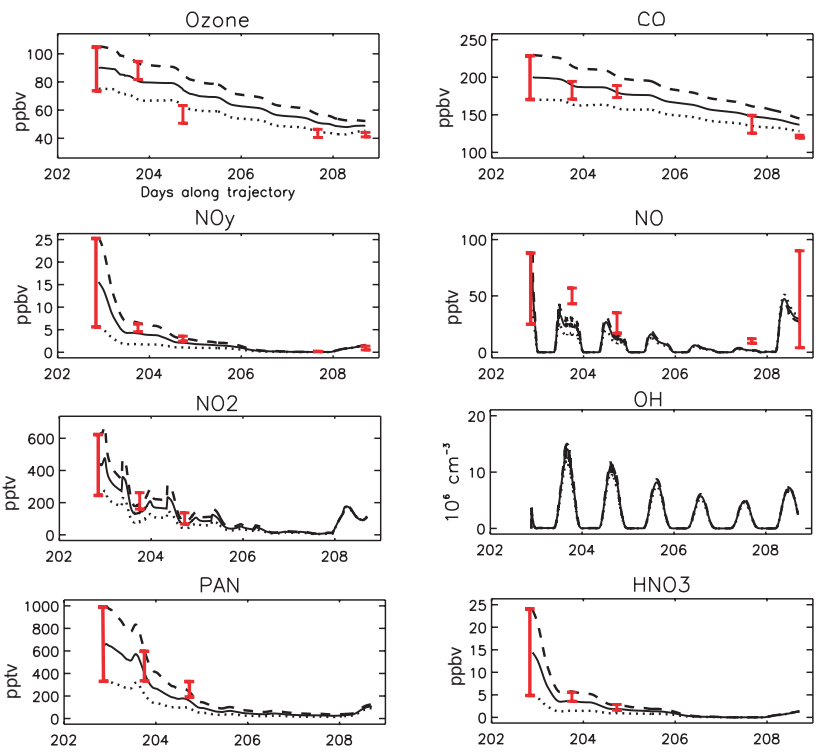

Fig. 9. Modelled concentrations versus time (Julian days) for runs including chemical, deposition and mixing processes using mean \pm std concentrations (same as Fig. 4).

than measurements from George et al. (1999) in recent polluted plumes and in better agreement with Ehhalt and Roher (2000). Moreover, since modelled J-values and $\mathrm{O}_{3}$ agree well with the data we can have some confidence in $\mathrm{OH}$ results.

It is also interesting to re-examine the comparison with measured VOCs. Whereas all VOCs measured on 25 July were underestimated in the run with chemistry only, the model results including deposition and mixing for the long lived VOCs are now in better agreement with the data mainly because of the decrease in modelled OH. For example, on 25 July, the comparisons are $1076 \mathrm{pptv}, 159 \mathrm{pptv}$ and $22 \mathrm{pptv}$ for modelled $\mathrm{C}_{2} \mathrm{H}_{6}, \mathrm{C}_{2} \mathrm{H}_{2}$ and $\mathrm{C}_{4} \mathrm{H}_{10}$ compared to measured values of $1075 \mathrm{pptv}, 169 \mathrm{pptv}$ and $25 \mathrm{pptv}$, respectively. On the other hand, modelled $\mathrm{C}_{2} \mathrm{H}_{4}$ and $\mathrm{C}_{3} \mathrm{H}_{6}$, with shorter lifetimes of 2 and 0.8 days, respectively, are almost zero whereas the data in the Lagrangian match shows values around $100 \mathrm{pptv}$ for both gases. Since it is unlikely that a plume older than 5 days would have such high concentrations it is possible that the plume was mixed with air masses influenced by local oceanic or biogenic emissions off the coast of Ireland (Heard et al., 2006). Such air masses with elevated levels of alkenes and low $\mathrm{CO}$ and $\mathrm{O}_{3}$ were measured off the Ireland coast on the same day by the Falcon.

\subsubsection{Influence of the different processes on plume concen- trations}

By analysing simulated $\mathrm{O}_{3}$ production and destruction terms, the influence of chemical, deposition and mixing processes on $\mathrm{O}_{3}$ can be evaluated. In the runs including all processes, and giving the best agreement with the data, a decrease of 

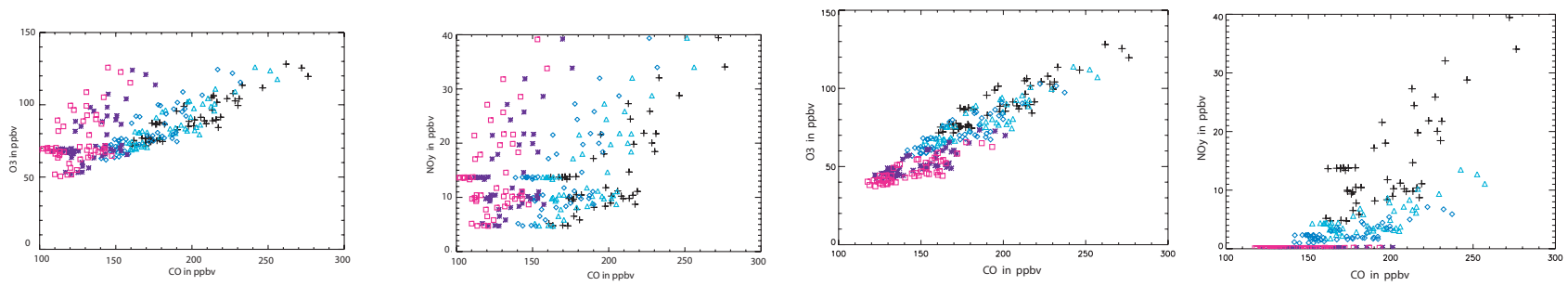

Chemistry only simulation.

Simulation including deposition.
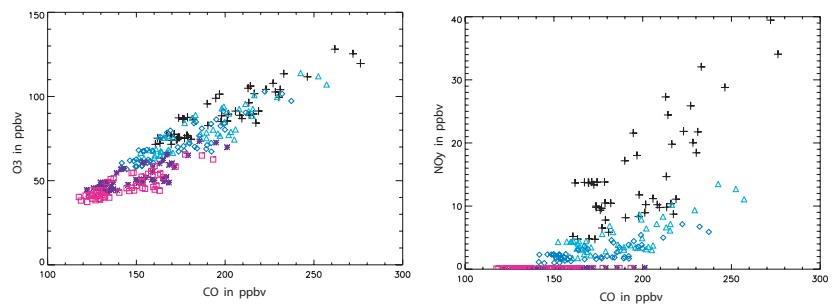

Simulation including deposition and mixing.

Fig. 10. Simulated concentrations of $\mathrm{O}_{3}$ and $\mathrm{NO}_{\mathrm{y}}$ versus $\mathrm{CO}$ in the 5 Lagrangian samplings. Black crosses represent measurements during the 20 July Lagrangian match and green triangles, blue diamonds, pink squares and violet stars show the modelled concentrations during the 21, 22, 25 and 26 Lagrangian samplings, respectively.

Table 4. Measured and simulated $\mathrm{O}_{3} / \mathrm{CO}$ and $\mathrm{NO}_{\mathrm{y}} / \mathrm{CO}$ correlation slopes with and without mixing and deposition during $\mathrm{P} 3$ matches on 20 , 21 and 22 July and Falcon matches on 25 and 26 July. Measured correlation coefficients, $r$, are also reported in brackets.

\begin{tabular}{lllll}
\hline & $\begin{array}{l}\text { Measured } \\
\text { slopes }\end{array}$ & $\begin{array}{l}\text { Simulated without mixing } \\
\text { or deposition (Case a) }\end{array}$ & $\begin{array}{l}\text { Simulated with deposition } \\
(\text { Case b) }\end{array}$ & $\begin{array}{l}\text { Simulated with deposition } \\
\text { and mixing (Case c) }\end{array}$ \\
\hline $\mathrm{P} 3-20: \mathrm{O}_{3} / \mathrm{CO}$ & $0.47(0.91)$ & & & \\
$: \mathrm{NO}_{\mathrm{y}} / \mathrm{CO}$ & $0.31(0.85)$ & & 0.46 & 0.46 \\
$\mathrm{P} 3-21: \mathrm{O}_{3} / \mathrm{CO}$ & $0.51(0.93)$ & 0.52 & 0.09 & 0.09 \\
$: \mathrm{NO} / \mathrm{CO}$ & $0.09(0.85)$ & 0.27 & 0.45 & 0.45 \\
$\mathrm{P} 3-22: \mathrm{O}_{3} / \mathrm{CO}$ & $0.17(0.21)$ & 0.59 & 0.05 & 0.05 \\
$: \mathrm{NO} / \mathrm{CO}$ & $0.02(0.3)$ & 0.29 & 0.36 & 0.37 \\
$\mathrm{Falcon} 25: \mathrm{O}_{3} / \mathrm{CO}$ & $-0.03(-0.12)$ & 0.69 & 0.0015 & 0.0015 \\
$: \mathrm{NO}_{\mathrm{y}} / \mathrm{CO}$ & $0.001(0.32)$ & 0.3 & 0.33 & 0.33 \\
Falcon $26: \mathrm{O}_{3} / \mathrm{CO}$ & $-0.31(-0.35)$ & 0.66 & 0.0011 & 0.0011 \\
$: \mathrm{NO}_{\mathrm{y}} / \mathrm{CO}$ & $0.14(0.7)$ & 0.27 & & \\
\hline
\end{tabular}

$42 \mathrm{ppbv}$ in $\mathrm{O}_{3}$ concentrations over 6 days is calculated. Of this decrease $75 \%$ is due to chemical destruction, including the effects of dry and wet deposition on $\mathrm{O}_{3}$ production, which gives a mean net $\mathrm{O}_{3}$ production of -5 ppbv/day. The remaining $25 \%$ is due to direct $\mathrm{O}_{3}$ dry deposition (10\%) and mixing $(15 \%)$. Without wet and dry deposition the net $\mathrm{O}_{3}$ production is only $-1.1 \mathrm{ppbv} /$ day. This is mainly due to $\mathrm{HNO}_{3}$ photolysis providing a source of $\mathrm{NO}_{\mathrm{x}}$ as discussed previously. Thus, these model results show that deposition processes were indirectly responsible for $80 \%$ of the impact of photochemistry on $\mathrm{O}_{3}$, with the large majority (78\%) being due to wet deposition rather than dry deposition. Modelled CO decreases by $60 \mathrm{ppbv}$ which is in good agreement with the observed evo- lution in the plume. Analysis of model results shows that $66 \%$ is due to chemical destruction and $34 \%$ due to mixing and dilution of the plume. Therefore, in this case, photochemical processes governed the evolution of both $\mathrm{O}_{3}$ and $\mathrm{CO}$ in the plume. Whilst this has been shown previously to be the case for $\mathrm{O}_{3}$, this is the first time, to our knowledge, that photochemistry has been shown to be the dominant process governing $\mathrm{CO}$ evolution over a period of several days. If the plume had not been subject to deposition processes, it would have reached Europe with much higher $\mathrm{O}_{3}(80-$ 90 ppbv), and lower CO (120-140 ppbv). It can be envisaged that less polluted plumes originating from North America would reach Europe with even lower $\mathrm{CO}$ values due to 
strong $\mathrm{OH}$ oxidation, and may therefore not be detected using the methods often applied to diagnose pollutant plumes such as the application of $\mathrm{CO}$ thresholds ( $\mathrm{Li}$ et al., 2002). This point is discussed further in the next section.

\subsection{Trace gas correlations}

Comparison of the full range of observed and simulated concentrations in the Lagrangian match samplings, and their inter-relationships can provide useful additional information about the evolution of pollutant concentrations in a plume, than just comparing modelled and measured means \pm std along a trajectory. Observed correlations in the Lagrangian matches have already been discussed in Sect. 2. In this section, multiple runs are used in order to characterise the variability across the Lagrangian samplings in an attempt to reproduce and understand the observed changes using the correlation between trace species. This method has already been used successfully to the forest fire case sampled during ICARTT (Real et al., 2007).

Multiple model runs were initialised with P3 measurements averaged every 30s during 20 July Lagrangian match samplings. With this method, each run represents a different part of the initial correlation (black crosses in Fig. 10) observed by the $\mathrm{P} 3$. Model results $\left(\mathrm{O}_{3} / \mathrm{CO}\right.$ and $\left.\mathrm{NO}_{\mathrm{y}} / \mathrm{CO}\right)$ after 1 (green triangles), 2 (blue diamonds), 4 (pink squares) and 5 (violet stars) days are shown in Fig. 10 for 3 cases : chemistry-only simulations (case A), simulations with chemistry and wet plus dry deposition (case B), and simulations with chemistry, deposition and mixing (case C). The simulated slopes for the different cases are reported in Table 4.

It has already been seen in Sect. 4.1 that the chemistryonly runs were unable to reproduce the chemical evolution of the plume but, nevertheless, it is still interesting to examine the evolution of the slopes in the case without deposition or mixing. The $\mathrm{O}_{3} / \mathrm{CO}$ and $\mathrm{NO}_{\mathrm{y}} / \mathrm{CO}$ simulated in case $\mathrm{A}$ are very different from those observed. The slopes increase with time whereas the data show an overall decrease. The modelled increase is not due to an increase in $\mathrm{NO}_{\mathrm{y}}$ or $\mathrm{O}_{3}$ that remains nearly constant, but is due to the strong chemical destruction of $\mathrm{CO}$ in these runs. Therefore, in the run with chemistry only, an increase in the $\mathrm{O}_{3} / \mathrm{CO}$ slope is the result of a decrease in $\mathrm{CO}$, and not the result of photochemical $\mathrm{O}_{3}$ production as is often stated (Andreae et al., 1994; Mauzerall et al., 1998). Along the same lines, Chin et al. (1994) showed that a decrease in $\mathrm{O}_{3} / \mathrm{CO}$ slopes could be due to the secondary production of $\mathrm{CO}$ by hydrocarbon oxidation in a fresh plume, and not just due to chemical destruction or deposition of $\mathrm{O}_{3}$. When deposition processes are included (case $\mathrm{B}$ ), $\mathrm{NO}_{\mathrm{y}} / \mathrm{CO}$ slopes show very good agreement with those observed on 21 and 25 July but not on 26 July. Modelled $\mathrm{O}_{3} / \mathrm{CO}$ slopes now decrease but less than observed on 25 July. Because mixing is simulated as a homogeneous process, modelled slopes change little between cases B and C due to small changes in $\mathrm{O}_{3}$ production. However, the corre-

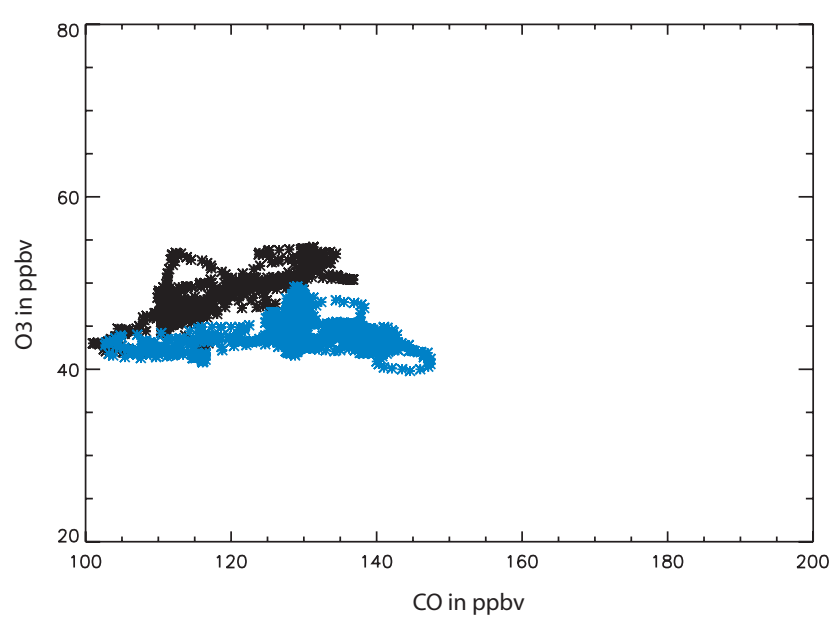

Fig. 11. Measured $\mathrm{O}_{3}$ versus $\mathrm{CO}$ concentrations during the 25 July Lagrangian match from 15:54 to 16:09 (blue crosses, part 1) and from 16:09 to 16:21 (black crosses, part 2). See text for discussion.

lation lines are shifted towards "background" concentrations, and the dispersion is reduced (see also discussion in Real et al., 2007). This leads to better overall agreement with the data in this correlation space although there are still some differences. The bad match between measurements and simulations on the 22 July has already been identified using the analysis based on comparison with mean observed values in the Lagrangian matches (Sect. 4.1) and is not discussed further.

Interestingly, this approach shows differences in measured and modelled $\mathrm{O}_{3} / \mathrm{CO}$ slopes ( -0.03 and 0.36 , respectively) on 25 July that were not apparent in the analysis using mean concentrations when model results agreed well with data. Further analysis based on the correlations suggests that the measurements in this Lagrangian match can be divided into 2 different parts, from 15:54 to $16: 06$ and 16:06 to $16: 21$, and 2 different air masses may have in fact been sampled. This distinction is shown in Fig. 11 based on the observed $\mathrm{O}_{3} / \mathrm{CO}$ correlation. For the first segment, $\mathrm{CO}$ and $\mathrm{O}_{3}$ are not really correlated, with a slope of 0.02 whereas for the second segment, the slope is positive with a value of 0.28 , and a correlation coefficient of 0.75 . This slope is comparable to measured values at ground-based sites such as Mace Head (Li et al., 2002). It is also closer to the simulated slope (0.36) whereas the weak slope in the first segment is not reproduced by the model runs initialised with measurements on 20 July. Therefore, it seems that the second segment represents the best match with the plume from 20 July whereas the first segment appears to have been influenced by inhomogeneous mixing at the edges of the plume, possibly with marine air masses, and not reproduced by the model.

The last important difference between modelled and measured $\mathrm{NO}_{\mathrm{y}} / \mathrm{CO}$ slopes is seen in the evolution between the 
25 and 26 July. The observed slopes are particularly much steeper on 26 July compared to 25 July. The Lagrangian plume appears to have been strongly dispersed by the time it it reached the English Channel on 26 July and influenced by fresh emissions with very high levels of $\mathrm{NO}$ and $\mathrm{NO}_{\mathrm{y}}$, as noted previously. The model does not capture this variability since the plume is not mixed with the full range of concentrations in this local plume but only with mean concentrations. Therefore, this last sampling cannot be considered as Lagrangian because of the strong influence of recent emissions.

\section{Conclusions}

The case of an anthropogenic plume transported from North America (New York-Boston region) over the North Atlantic to Europe at low altitudes has been studied in a Lagrangian framework. This plume was initially strongly polluted with high concentrations of $\mathrm{O}_{3}, \mathrm{CO}$ and $\mathrm{NO}_{\mathrm{x}}$, typical of North American polluted plumes, and also very high levels of $\mathrm{HNO}_{3}$. During transport, all pollutant concentrations decreased, and the plume was much less polluted when it was intercepted off the west coast of Ireland several days later. A Lagrangian photochemical model (CiTTyCAT), has been used to assess the different processes influencing the evolution of pollutant levels in the plume during long-range transport. Average concentrations and correlations between trace species $\left(\mathrm{O}_{3} / \mathrm{CO}\right.$ and $\left.\mathrm{NO}_{\mathrm{y}} / \mathrm{CO}\right)$ have been examined and compared to data collected in the Lagrangian match segments. Overall, the analysis suggests that some of the links identified as Lagrangian by Methven et al. (2006) are not truly Lagrangian, in particular on 22 July because of probable errors in ECMWF coastal winds and on 26 July due to the influence of local emissions. In addition, the analysis of trace gas correlations showed that part of the match on 25 July is not closely linked to 20 July.

The evolution of the chemical composition in the plume (mean values and correlations) is best reproduced when photochemistry, dry/wet deposition and mixing with surrounding air masses are all included. Model results show that these changes were mainly driven by photochemical and deposition processes, especially wet deposition. The impact of heterogeneous loss of $\mathrm{N}_{2} \mathrm{O}_{5}$ on aerosols can be important for $\mathrm{NO}_{\mathrm{x}}\left(50 \%\right.$ reduction) and $\mathrm{O}_{3}$ but much less in this case where wet deposition is the dominant factor affecting $\mathrm{NO}_{\mathrm{y}}$. Mixing with air masses in close proximity to the plume during transport did not have a strong impact on trace gas concentrations during the first 5 days due to strong and rapid transport by low level winds and isolation of the plume from the marine boundary layer over the Atlantic. Mixing with local pollution sources (possibly ships or urban sources) appears to have been important on 26 July.

Mean net $\mathrm{O}_{3}$ production in the plume was negative over the 6 day period averaging about $-5.0 \mathrm{ppbv} /$ day leading to average $\mathrm{O}_{3}$ concentrations of $44 \mathrm{ppbv}$ when it reached $\mathrm{Eu}-$ rope. This is low compared to values observed close to European sources but is significantly higher than levels observed over remote oceanic regions where the plume was sampled and so may represent a net import affecting background $\mathrm{O}_{3}$ levels over western Europe. Plume $\mathrm{O}_{3}$ was directly impacted by dry deposition, and indirectly by wet deposition through the strong scavenging of $\mathrm{HNO}_{3}$, mainly in the first couple of days of transport. This implies that, in this case, wet deposition was responsible for an $80 \%$ reduction in net photochemical $\mathrm{O}_{3}$ production. This study and the one from Neuman et al. (2006) show that, because polluted plumes from the NewYork/Boston region are very rich in $\mathrm{HNO}_{3}$, wet deposition can have a strong impact on $\mathrm{O}_{3}$ levels downwind. Runs with no wet deposition, showed that photolysis of $\mathrm{HNO}_{3}$ could maintain high $\mathrm{O}_{3}$ during plume transport leading to lower average net destruction $(-1.0 \mathrm{ppbv} / \mathrm{day})$. In that case, the plume would have reached Europe with $\mathrm{O}_{3}$ concentrations between 80 and $90 \mathrm{ppbv}$ resulting in a stronger import of $\mathrm{O}_{3}$ directly into the European BL.

Another important result is the dominant influence of photochemistry on $\mathrm{CO}$ concentrations in the plume rather than mixing and dilution which is usually assumed to be dominating over these time scales. In this case, photochemical destruction explains $66 \%$ of the $\mathrm{CO}$ decrease compared to only $34 \%$ due to mixing. This is due to relatively high $\mathrm{O}_{3}$ levels during the first few days coupled with high water vapour leading to a high oxidative capacity in the plume, and therefore a reduction in $\mathrm{CO}$ chemical lifetime to 23 days. This has several consequences. Firstly, these results show that, in this case of pollutant transport at low altitudes, CO cannot be always used as a tracer of anthropogenic pollution. This may also explain the low levels of $\mathrm{CO}$ often observed in plumes originating from North America and sampled downwind in the European BL. The latter does not imply that the plume was weakly polluted but that photochemistry was intense. Secondly, we have shown that an observed increase in $\mathrm{O}_{3} / \mathrm{CO}$ correlation slopes can result from photochemical destruction of $\mathrm{CO}$ and not photochemical production of $\mathrm{O}_{3}$ as is often assumed.

Overall, these results show that $\mathrm{O}_{3}$ import into downwind regions is sensitive to scavenging processes along route as well as photochemical processing and that $\mathrm{CO}$ levels can also be strongly influenced by photochemical loss as well as dilution and mixing. Whilst there are uncertainties related to this type of Lagrangian analysis including errors in trajectories, studies using this modelling framework are able to provide detailed insight into the processes governing pollutant plume evolution during long-range transport. These results can also be used to evaluate plume transport and processing in global models that typically have problems resolving such features.

Acknowledgements. Elsa Real and Kathy Law acknowledge financial support from national programmes (PNCA, PATOM) provided by INSU-CNRS, ADEME and also from Insitut Pierre 
Simon Laplace (IPSL) for the French ITOP project as well as the Institut Geographique National (IGN) for hosting the DLR Falcon campaign at Creil, France. We would like to thank the whole ICARTT team, and in particular P3 scientists.

Edited by: L. Carpenter

\section{References}

Andreae, M. O., Anderson, B. E., Blake, D. R., Bradshaw, J. D., Collins, J. E., Gregory, G. L., Sachse, G. W., and Shipham, M. C.: Influence of plumes from biomass burning on atmospheric chemistry over the equatorial and tropical South Atlantic during CITE3, J. Geophys. Res., 99, 12 793-12 808, 1994.

Arnold, S. R., Methven, J., Evans, M. J., Chipperfield, M. P., Lewis, A. C., Hopkins, J., McQuaid, J. B., Watson, N., Purvis, R. M., Lee, J. D., Atlas, E. L., Blake, D. R., and Rappenglück, B.: Quantification of mean $\mathrm{OH}$ concentration and air mass dilution rates from successive observations of non-methane hydrocarbons in single air masses, J. Geophys. Res., 112, D10S40, doi:10.1029/2006JD007594, 2006.

Auvray, M. and Bey, I.: Long-range transport to Europe: Seasonal variations and implications for the European ozone budget, J. Geophys. Res., 110, D11303, doi:10.1029/2004JD005503, 2005.

Chen, M., Talbot, R., Mao, H., Sive, B., Chen, J., and Griffin, R. J.: Air mass classification in coastal New England and its relationship to meteorological conditions., J. Geophys. Res., 112, D10S05, doi:10.1029/2006JD007687, 2007.

Chin, M., Jacob, D., Munger, J. W., Parrish, D. D., and Doddridge, B. G.: Relationship of ozone and carbon monoxide over North America, J. Geophys. Res., 99, 14 565-14 573, 1994.

Corbett, J. J. and Koehler, H. W.: Updated emissions from ocean shipping., J. Geophys. Res., 108, 4650, doi:10.1029/2003JD003751, 2003.

Crutzen, P. J. and Lawrence, M. G.: The impact of precipitation scavenging on the transport of trace gases: A 3-dimensional model sensitivity study, J. Atmos. Chem., 37, 81-112, 2000.

Derwent, R. G., Richard, G., Jenkin, M. E., Saunders, S. M., and Pilling, M. J.: Photochemical ozone creation potentials for organic compounds in northwest Europe calculated with a master chemical mechanism., Atmos. Environ., 32, 2429-2441, 1998.

Derwent, R. G., Ollins, D. S. S. W. J., and Johnson, E.: Intercontinental transport and the origins of the ozone observed at surface sites in Europe., Atmos. Environ., 38, 1891-1901, 2004.

Ehhalt, D. and Roher, F.: Dependence of the $\mathrm{OH}$ concentration on solar UV., J. Geophys. Res., 105, 3565-3571, 2000.

Evans, M. J., Shallcross, D. E., Law, K. S., Wild, J. O. F., Simmonds, P. G., Spain, T. G., Berrisford, P., Methven, J., Lewis, A. C., McQuaid, J. B., Pillinge, M. J., Bandyf, B. J., Penkett, S. A., and Pyle, J. A.: Evaluation of a Lagrangian box model using field measurements from EASE (Eastern Atlantic Summer Experiment) 1996, Atmos. Environ., 34, 3843-3863, 2000.

Fehsenfeld, F., Ancellet, G., Bates, T., Goldstein, A., Hardesty, M., Honrath, R., Law, K., Lewis, A., Leaitch, R., McKeen, S., Meagher, J. F., Pszenny, A., Russell, P., Schlager, H., Seinfeld, J., Trainer, M., Talbot, R., and Zbinden, R.: International Consortium for Atmospheric Research on Transport and Transformation (ICARTT) - North America to Europe: Overview of the 2004 summer field study, J. Geophys. Res., 111, D23S01, doi:10.1029/2006JD007829, 2006.

George, L. A., Hard, T. M., and O'Brian, R. J.: Measurements of free radicals $\mathrm{OH}$ and $\mathrm{HO}_{2}$ in Los Angeles smog, J. Geophys. Res., 104, 11 643-11 655, 1999.

Guerova, G., Bey, I., Attié, J.-L., Martin, R. V., Cui, J., and Sprenger, M.: Impact of transatlantic transport episodes on summertime ozone in Europe, Atmos. Chem. Phys., 6, 2057-2072, 2006 ,

http://www.atmos-chem-phys.net/6/2057/2006/.

Heard, D. E., Read, K. A., Methven, J., Al-Haider, S., Bloss, W. J., Johnson, G. P., Pilling, M. J., Seakins, P. W., Smith, S. C., Sommariva, R., Stanton, J. C., Still, T. J., Ingham, T., Brooks, B., De Leeuw, G., Jackson, A. V., McQuaid, J. B., Morgan, R., Smith, M. H., Carpenter, L. J., Carslaw, N., Hamilton, J., Hopkins, J. R., Lee, J. D., Lewis, A. C., Purvis, R. M., Wevill, D. J., Brough, N., Green, T., Mills, G., Penkett, S. A., Plane, J. M. C., Saiz-Lopez, A., Worton, D., Monks, P. S., Fleming, Z., Rickard, A. R., Alfarra, M. R., Allan, J. D., Bower, K., Coe, H., Cubison, M., Flynn, M., McFiggans, G., Gallagher, M., Norton, E. G., O’Dowd, C. D., Shillito, J., Topping, D., Vaughan, G., Williams, P., Bitter, M., Ball, S. M., Jones, R. L., Povey, I. M., O’Doherty, S., Simmonds, P. G., Allen, A., Kinnersley, R. P., Beddows, D. C. S., Dall'Osto, M., Harrison, R. M., Donovan, R. J., Heal, M. R., Jennings, S. G., Noone, C., and Spain, G.: The North Atlantic Marine Boundary Layer Experiment(NAMBLEX). Overview of the campaign held at Mace Head, Ireland, in summer 2002, Atmos. Chem. Phys., 6, 2241-2272, 2006,

http://www.atmos-chem-phys.net/6/2241/2006/.

Honrath, R. E., Owen, R. C., Martin, M. V., Reid, J. S., Lapina, K., Fialho, P., Dziobak, M. P., Kleissl, J., and Westphal, D. L.: Regional and hemispheric impacts of anthropogenic and biomass burning emissions on summertime $\mathrm{CO}$ and $\mathrm{O}_{3}$ in the North Atlantic lower free troposphere., J. Geophys. Res., 109, D24310, doi:10.1029/2004JD005147, 2004.

Hough, A.: The calculation of photolysis rates for use in global troposheric modeling studies, Tech. rep., Energy Res. Estab., Her Majesty's Stn. Off., London, 1988.

Huntrieser, H., Heland, J., Schlager, H., Forster, C., Stohl, A., Aufmhoff, H., Arnold, F., Scheel, H. E., Campana, M., Gilge, S., Eixmann, R., and Cooper, O.: Intercontinental air pollution transport from North America to Europe: Experimental evidence from airborne measurements and surface observations., J. Geophys. Res., 110, D01305, doi:10.1029/2004JD005045, 2005.

Li, Q., Jacob, D. J., Bey, I., Palmer, P., Duncan, B. N., Field, B. D., Martin, R. V., Fiore, A. M., Yantosca, R. M., Parrish, D. D., Simmonds, P. G., and Oltmans, S. J.: Transatlantic transport of pollution and its effects on surface ozone in Europe and North America., Atmos. Environ., 107(D13), 4166, doi:10.1029/2001JD001422, 2002.

Li, Q., Jacob, D. J., Park, R., Wang, Y., Heald, C., Hudman, R., Yantosca, R., Martin, R., and Evans, M.: North American pollution outflow and the trapping of convectively lifted pollution by upper-level anticyclone., J. Geophys. Res., 110, D10301, doi:10.1029/2004JD005039, 2005.

Mauzerall, D. L., Logan, J. A., Jacob, D. J., Anderson, B. E., Blake, D. R., Bradshaw, J. D., Haikes, B., Sachse, G. W., Singh, H., and Talbot, B.: Photochemistry in biomass burning plumes and implications for tropospheric ozone over the tropical South At- 
lantic, J. Geophys. Res., 103, 8401-8423, 1998.

Methven, J., Arnold, S. R., Stohl, A., Avery, M., Law, K., Lewis, A., Parrish, D., Reeves, C., Schlager, H., Atlas, E., Blake, D., and Rappenglück, B.: Establishing Lagrangian connections between observations within air masses crossing the Atlantic during the ICARTT experiment, J. Geophys. Res., 111, D23S62, doi:10.1029/2006JD007540, 2006.

Millet, D. B., Goldstein, A. H., Holzinger, R., Williams, B. J., Allan, J. D., Jimenez, J. L., Worsnop, D. R., Roberts, J. M., White, A. B., Hudman, R. C., Bertschi, I. T., and Stohl, A.: Chemical characteristics of North American surface layer outflow: Insights from Chebogue Point Nova Scotia, J. Geophys. Res., 111, D23S53, doi:10.1029/2006JD007287, 2006.

Mozurkevich, M. and Calvert, J.: Reaction Probability of N205 on Aqueous Aerosols, JGR, 93, 15 889-15 896, 1988.

Neuman, J. A., Parrish, D. D., Trainer, M., Ryerson, T. B., Holloway, J. S., Nowak, J. B., Swanson, A., Flocke, F., Roberts, J. M., Brown, S. S., Stark, H., Sommariva, R., Stohl, A., Peltier, R., Weber, R., Wollny, A. G., Sueper, D. T., Hubler, G., and Fehsenfeld, F. C.: Reactive nitrogen transport and photochemistry in urban plumes over the North Atlantic Ocean, J. Geophys. Res., 111, D23S54, doi:10.1029/2005JD007010, 2006.

Owen, R. C., Cooper, O. R., Stohl, A., and Honrath, R. E.: An analysis of the mechanisms of North American pollutant transport to the central North Atlantic lower free troposphere., J. Geophys. Res., 111, D23S58, doi:10.1029/2006JD007062, 2006.

Parrish, D. D., Holloway, J. S., Trainer, M., Murphy, P. C., Forbes, G. L., and Fehsenfeld, F. C.: Relationship between ozone and carbon monoxide at surface sites in the North Atlantic region, J. Geophys. Res., 103, 13 357-13 376, 1998.

Penner, J. E., Atherton, C. S., Dignon, J., Ghan, S. J., and Walton, J. J.: Tropospheric nitrogen: a three-dimensional study of sources, distribution and deposition, J. Geophys. Res., 96, 959990, 1991

Price, H. U., Jaffe, D. A., Cooper, O. R., and Doskey, P. V.: Photochemistry, ozone production, and dilution during long-range transport episodes from Eurasia to the northwest United States, J. Geophys. Res., 109, D23S13, doi:10.1029/2003JD004400, 2004.

Real, E., Law, K. S., Wienzierl, B., Fiebig, M., Petzold, A., Wild, O., Methven, J., Arnold, S., Stohl, A., Huntrieser, H., Roiger, A., Schlager, H., Stewart, D., Avery, M., Sachse, G., Browell, E., Ferrare, R., and Blake, D.: Processes influencing ozone levels in Alaskan forest fires plumes during long-range transport over the North Atlantic, J. Geophys. Res., 112, D10S41, doi:10.1029/2006JD007576, 2007.
Riddle, E. E., Voss, P. B., Stohl, A., Holcomb, D., Maczka, D., Washburn, K., and Talbot, R. W.: Trajectory model validation using newly developed altitude-controlled balloons during the International Consortium for Atmospheric Research on Transport and Transformations 2004 campaign, J. Geophys. Res., 111, D23S57, doi:10.1029/2006JD007456, 2006.

Rossow, W. B. and Schiffer, R. A.: ISCCP cloud data products, Bull. Am. Meteorol. Soc., 72, 2-20, 1991.

Schubert, S. D., Rood, R. B., and Pfaendtner, J.: An assimilated data set for earth science applications, Bull. Am. Meteorol. Soc., 74, 2331-2342, 1993.

Stohl, A.: A 1-year Lagragian "climatology" of airstreams in the Northern hemisphere troposphere and lowermost stratosphere, J. Geophys. Res., 106, 7263-7279, 2001.

Stohl, A., Wotawa, G., Seibert, P., and Kromp-Kolb, H.: Interpolation errors in wind fields as a funcion of spatial and temporal resolution and their impact on different types of kinematic trajectories, J. Appl. Meteorol., 34, 2149-2165, 1995.

Stohl, A., Eckhardt, S., Forster, C., James, P., and Spichtinger, N.: On the pathways and timescales of intercontinental air pollution transport, J. Geophys. Res., 107, (D23)4684, doi:10.1029/2001JD001396, 2002.

Stohl, A., Cooper, O. R., Damoah, R., Fehsenfeld, F. C., Forster, C., Hsie, E.-Y., Hbler, G., Parrish, D. D., and Trainer, M.: Forecasting for a Lagrangian aircraft campaign, Atmos. Chem. Phys., 4, 1113-1124, 2004, http://www.atmos-chem-phys.net/4/1113/2004/.

Walton, J. J., Maccracken, M. C., and Ghan, S. J.: A global-scale lagrangian trace species model of transport, transformation, and removal processes, J. Geophys. Res., 93, 8339-8354, 1988.

Warneke, C., de Gouw, J. A., Goldan, P. D., Kuster, A. C., Williams, E. J., Lerner, B. M., Jakoubek, R., Brown, S. S., Stark, H., Aldener, M., Ravishankara, A. R., Roberts, J. M., Marchewka, M., Bertman, S., Sueper, D. T., McKenne, S. A., Meagher, J. F., and Feshenfeld, F. C.: Comparison of daytime and nightime oxidation of biogenic VOCs along the New England coast in summer during New England Air Quality Study 2002., J. Geophys. Res., 109, D10309, doi:10.1029/2003JD004424, 2004.

Wentz, F. J. and Spencer, R. W.: SSMI/I rain retrievals within a unified all-weather ocean algorithm, J. Atmos. Sci., 55, 1149$1152,1998$.

Wild, O. and Akimoto, H.: Intercontinental transport of ozone and its precursors in a three-dimensional global CTM, J. Geophys. Res., 106, 27 729-27 744, 2001.

Wild, O., Law, K. S., McKenna, D. S., Bandy, B. J., Penkett, S. A., and Pyle, J. A.: Photochemical trajectory modeling studies of the North Atlantic region during August 1993, J. Geophys. Res., 101, 29 269-29288, 1996. 